CIRJE-F-805

\title{
Interbank Networks in Prewar Japan: Structure and Implications
}

\author{
Tetsuji Okazaki \\ University of Tokyo \\ Michiru Sawada \\ Nihon University
}

July 2011

CIRJE Discussion Papers can be downloaded without charge from:

http://www.cirje.e.u-tokyo.ac.jp/research/03research02dp.html

Discussion Papers are a series of manuscripts in their draft form. They are not intended for circulation or distribution except as indicated by the author. For that reason Discussion Papers may not be reproduced or distributed without the written consent of the author. 


\title{
Interbank Networks in Prewar Japan: Structure and Implications
}

\author{
Tetsuji Okazaki*(Faculty of Economics, The University of Tokyo, Tokyo, Japan) \\ and \\ Michiru Sawada** (Nihon University College of Economics, Tokyo, Japan)
}

\begin{abstract}
In this paper, we explore the structure and implications of interbank networks in prewar Japan, focusing on director interlocking. We find that approximately half the banks had at least one connection with another bank through director interlocking, and that a bank that had connections with other banks was less likely to fail than a bank without a network. The quality of networks also matters in the sense that the failure probability of a bank with a network was negatively associated with the profitability of the connected banks. On the other hand, there is no strong evidence of financial contagion through networks. In addition, networks of director interlocking contributed to the stabilization of the financial system through coordinating bank mergers.
\end{abstract}

JEL Classification: G21, G34, L14, L22, N25

Key Words: Networks, Banks, Director Interlocking, Mergers, Japan

\footnotetext{
*E-mail address:okazaki@e.u-tokyo.ac.jp.

** E-mail address: sawada.michiru@nihon-u.ac.jp
} 


\section{Introduction}

Social network analysis has been developing in the fields of sociology and mathematics for the past 50 years. Meanwhile, in the field of economics, the number of studies on networks has surged over the past decade. Some of these studies use game theoretical models to investigate how networks form when a person strategically constructs links with others, and how stable and efficient such networks are (Jackson 2003, 2006; Goyal 2007). Other studies have applied network analysis to investigate economic phenomena such as mutual insurance among villagers (Fafchamps and Gubert 2007), informal credit among firms (Macmillan and Woodruff 1999), and welfare participation (Bertland et al. 2000). These studies focus on the effects of networks on economic behavior and outcomes.

In recent years, social networks through boards of directors have attracted attention in various research fields, e.g., statistical physics, economics, sociology and management, among others ${ }^{1}$. In particular, current research in financial economics investigates how director interlocking affects the firm performance or the effectiveness of monitoring by the board. Some studies hypothesize that directors serving on multiple boards are too busy to perform their monitoring roles effectively, and find supporting empirical evidence that reveals that firms with interlocking directors are associated with lower performance, lower sensitivity of COE turnover to firm performance and negative evaluation from stock markets (Fich and Shivdasani 2006, Non and Franses 2007, Devos et al. 2009, and Croci and Grassi 2010). Furthermore, other studies find

\footnotetext{
${ }^{1}$ Research in the field of statistical physics and computational organization science captures quantitatively the structure of networks through interlocking directors. There, it is generally observed that these networks are assortative, highly clustered, and dominated by a giant component and small worlds (Davis et al. 2003; Battiston and Catanzaro 2004; Robins and Alexander 2004; Conyon and Muldoon 2006; Milakovic et al. 2010).
} 
that firms with interlocked boards are likely to award higher compensation (Hallock 1997; Barnea and Guedj 2006).

On the other hand, director interlocking may facilitate sharing and transmitting useful information about business practices and strategies, and if this is the case, director interlocking can be beneficial to firms ${ }^{2}$. Consistent with this hypothesis, Loderer and Peyer (2002) and Perry and Peyer (2005) obtained empirical evidence that director interlocks positively affect firm value ${ }^{3}$. In addition, some recent studies examine directly whether financial practices are transferred through board interlocking, and find that networks through board interlocks affected the adoption of poison pills (Davis 1991). Some studies also find that such networks contributed to the spread of the practice of backdating stock option grants to their executives (Bizjak et al. 2009), and increased the likelihood of being the target of a private equity (PE)-based take-private transaction (Stuart and Yim 2010).

Meanwhile, in the literature on money and banking, recent theoretical research investigates how a shock to one bank spreads contagiously to other banks, and how the possibility of contagion is associated with the structure of interbank networks (Allen and Gale 2000; Freixas et al. 2000; Dasgupta 2004; Leinter 2005; Brusco and Castiglionesi 2007; Gai and Kapadia 2010)4. Based on these theoretical frameworks, several empirical

\footnotetext{
2 Based on resource dependence theory, Preffer and Salanik (1978) suggest that interlocking boards can play a role in facilitating communication and buffering the effect of environmental uncertainty. In addition, there are numerous studies in the field of management that show that corporate strategies or business practices can be transferred between firms through the networks of director interlocking (Palmer et al. 1993; Haunschild 1993; Westphal and Zajac 1997; Rao and Sivakumar 1999; etc.).

${ }^{3}$ Perry and Peyer document that interlocks raise firm value when executives are appointed in financial, high-growth, or related-industry firms. Loderer and Peyer (2002) show that the number of board seats in listed firms held by the chairman of a firm positively affects the value of the firm based on the Swiss data. In addition, Fama and Jensen (1983) argue that the number of directorships can be a signal of directors' competence. In this case also, director interlocking can raise firm value.

4 See Allen and Babus (2009) for a comprehensive survey.
} 
studies have simulated the possibility of financial contagion (Sheldom and Maurer 1998; Furine 2003; Upper and Worms 2004; Degryse and Ngyuen 2007). Recent empirical literature also analyzes financial contagion through interbank loan networks, using the actual event of the bank failure. Iyer and Peydro (2010), for example, find evidence that banks with higher exposures to the failed bank in the interbank market experienced larger deposit withdrawals, using the failure of a large cooperative bank in India ${ }^{5}$.

In this paper, we explore the structure and implications of interbank networks through director interlocking in Japan before the Second World War. Prewar Japan has a number of attractive features for the empirical study of corporate networks. First, there were indeed many corporate networks, in particular networks among banks. Many large investors held blocks of shares in and directorships of multiple banks, and as a result, banks connected with other banks through director interlocking and ownership to form networks (Okazaki et al. 2005, 2007). Second, rich relevant data are available. From company directories, we can compile a comprehensive database of directors to identify interbank networks through director interlocking. In addition, comprehensive financial data on banks are available from the official publications of the Ministry of Finance. Third, in that period, the Japanese financial system experienced financial crises and a wave of bank mergers and exits. These events provide us with a good opportunity to examine the implications of interbank networks for stability/instability of the financial system.

Using a newly compiled data set, we investigate how a network affected bank survivability, taking into account its quality and structure, whether a network promoted bank consolidations, and how it affected post-merger performance. In addition, we examine the possibility of financial contagion through the network of interlocking

${ }^{5}$ In addition, Carson et al. (2010) showed that the failures of large banks increased the probability of failures of other banks through correspondent relationships. 
boards ${ }^{6}$. Thus, we test whether withdrawals of deposits spread through director networks, using the data of the Showa Financial Crisis of 1927, when a nationwide bank run occurred.

The remainder of the paper is organized as follows. Section 2 describes the characteristics of interbank networks based on director interlocking in prewar Japan. Section 3 examines the effects of interbank networks on the survivability of banks. In Section 4, we investigate the effects of the interbank networks on financial contagion. In Section 5, we analyze how an interbank network affected the choice of counterpart banks in consolidations, and examine how consolidations based on interbank networks differed from the other consolidations in terms of post-merger performance. Section 6 concludes the paper.

\section{Structure and Quality of Networks}

As stated above, in prewar Japan, many large investors held blocks of shares in, and directorships of, multiple banks, and as a result, there were many interbank networks through director interlocking and ownership. Because of limitations of ownership data, we identify interbank networks by focusing on director interlocking. The data sources are the 1926 and 1931 issues of the Directory of Banks and Companies (Ginko Kaisha Youroku) produced by a major private credit bureau, Tokyo Koshinjo ${ }^{7}$.

${ }^{6}$ Interbank networks based on director interlocking may constitute a channel of financial contagion. At the same time, however, networks among banks may enhance the durability of banks, as did the shift from unit banking to branch banking (Calomiris 1990).

7 The Directory of Banks and Companies was used by Okazaki et al. (2005). Tokyo Koshinjo, one of the largest private credit bureaus in prewar Japan, published a directory of corporate directors, Ginko Kaisha Youroku, every year from 1897 to 1942. 
The Directory of Banks and Companies covers directors and auditors of the banks and nonbanking firms whose paid-in capital was not less than 200,000 yen ${ }^{8}$. We selected the year 1926 for analysis because thereafter the financial system became unstable and a huge wave of bank mergers and exits took place (Okazaki and Sawada 2007; Okazaki et al. 2007) ${ }^{9}$. Hence, we can observe the role of interbank networks under the unstable financial system. In addition, we selected the year 1931 to see the effect of interbank networks on bank performance during a normal period. After the Showa Depression of 1930-31, the Japanese economy recovered quickly and was not exposed to large negative shocks.

The financial data of each bank for 1926 and 1931 are taken from the 1927 and 1932 issues of the Yearbook of the Bank Bureau (Ginkokyoku Nenpo) published by the Ministry of Finance, which covers all the banks in Japan, excluding its colonies. The number of banks commonly included in these two sources is 1,007 for 1926 and 597 for $1931^{10}$

By using the Directory of Banks and Companies, we identify that a given pair of banks had a connection if a person served concurrently as a director of both banks. Even if a certain bank (Bank A) had two directors who also held directorships in the other bank (Bank B), the number of connections between Bank A and Bank B is counted as one. Our measure of interbank networks-relationships through director interlocking-is designed to capture not just human relationships but also broader

8 Conveniently, this source includes a name index. This index lists all the banks and nonbanking companies in which named individuals had directorships.

9 The Bank Law set banks' minimum capital requirements, which many banks were unable to meet. Those banks were practically obliged to merge with another bank or face liquidation. We discuss this law in more detail in Section 5.

10 Ginkokyoku Nenpo covers 1,417 (683) ordinary banks in Japan, excluding its colonies, as at the end of 1926 (1931). Complete financial data are available for 1,398 (636) of the 1,417 (683) banks. Data on directors and auditors are available from Ginko Kaisha Youroku for 1,007 (597) banks. 
aspects of relationships among the relevant banks, namely, ownership, interbank loans, and correspondence relationships. Imuta (1980) pointed out that directorship connections represented deeper relationships than did correspondent and interbank loan relationships.

This point is illustrated by the following two cases where detailed information on financial transactions is available. First, Imuta (1980) shows the correspondent relationships of Oshi Shogyo Bank prevailing at the end of 1930. Oshi Shogyo Bank, the third-largest bank in Saitama Prefecture at the time, had correspondent agreements with 656 headquarters and branches of 116 private banks. Out of the 656 agreements, 20 were with the headquarters and branches of Ashikaga Bank, and this number of agreements was the third largest, except for the four zaibatsu banks, which had nationwide branch networks and were major correspondents of many banks. Meanwhile, Oshi Shogyo Bank only had director interlocking with Ashikaga Bank in 1930. These facts suggest that director interlocking was associated with correspondent relationships between the two banks.

Second, as for interbank loan relationships, we look at the case of Daihyakusanjusan Bank, the second-largest bank in Shiga Prefecture in 1926. Detailed accounting records for Daihyakusanjusan Bank are held at the Archival Museum of the Faculty of Economics, Shiga University. A series of accounting records entitled Taten Kanjo Motocho (Ledger on Branches of Other Banks) provides information about the account balances between Daihyakusanjusan Bank and the branches of other banks. At the end of 1926, Daihyakusanjusan Bank was in a net borrowing position with 74 banks, and its total net borrowing amounted to 618,180 yen. At the same time, it had a net lending position with 19 banks, and its total net lending amounted to 8,866 yen. It is significant that the largest contribution to its net borrowing, 275,768 yen, was from Yamaguchi Bank, which was the only bank with which Daihyakusanjusan Bank had 
director interlocking. This fact suggests that director interlocking was associated with interbank loans. In summary, these two cases suggest that our measure of interbank networks, director interlocking, is significant for capturing interbank financial relationships. Hence, we use this measure in the analysis of financial contagion in Section 4 .

Table 1 presents the distribution of the numbers of connections that individual banks had in 1926 and 1931. As shown in this table, 587 of 1,007 banks (58.3\%) had at least one connection with another bank through director interlocking in 1926 (Panel A), as did 271 of 597 banks (45.4\%) in 1931 (Panel B). The number of connections in Table 1 corresponds to the "degree" concept from the social network analysis literature. In this literature, the degree, i.e., the number of relations a certain node has with other nodes, is supposed to be a measure of the "centrality" of the former node in the network. That is, the more relations a node has with other nodes within a network, the more central or important in the network that node is considered to be (Wasserman and Faust 1994; Jackson 2008; etc.).

In Table 2, we examine the structure of the director interlocking networks in more detail with respect to banks with at least one degree (587 banks in 1926 and 271 banks in 1931). First, to have an overview of the structure network, we divide them into components, in the sense of the graph theory. A component is defined as a subgraph where all pairs of nodes in it are reachable through their connections. We counted the number of components for 1926 and 1931, and found there were 137 and 75 components in 1926 and 1931, respectively. Panel A of Table 2 presents the distribution of the size of components (the number of nodes in each component). Most of the components consisted of 2-4 nodes (banks) in both 1926 and 1931, which suggests that the network of director interlocking in prewar Japanese banking industry was characterized by numerous small-sized subnetworks. This observation is in contrast with preceding literature on 
the network structure of director interlocking, which mostly reports that the network of director interlocking is dominated by a giant component (Battiston and Catanzaro 2004, Brrokfiel 2009, Milakovic et al. 2010, among others).

In Panel B, we calculate various network measures in addition to "degree," that is, "clustering coefficient," "core degree," “average nearest neighbor degree," and "assortativity coefficient" 11 . "Clustering coefficient" is a measure of density of connections around a node ${ }^{12}$. That is, it represents the ratio of the number of links (connections) in the neighborhood (adjacent nodes) of a node to the number of links (connections) if the neighborhood was completely connected ${ }^{13}$. Panel B shows that the clustering coefficient is 0.24 in 1926 and 0.19 in 1931 . Those values are not as high as those found in other research on director interlocking (Battiston and Catanzaro 2004; Brrokfiel 2009), probably because the network structure of prewar Japan was composed of small-sized subnetworks, as shown in Panel A.

"Core degree" indicates the extent to which a bank belongs to a high-density subnetwork (subgraph). Generally, $k$-core is a subnetwork in which each node has at least $\mathrm{k}$ links (connections) in the same subnetwork (subgraph). The number of $k$ is called the core degree. Panel B reports that the value of the core degree is around 1.5. This result is also likely to reflect that there were many subnetworks composed of only two banks. In summary, the network structure of director interlocking was not highly dense as a whole.

11 There are two well-known measures of "centrality" in addition to degree centrality, namely, "closeness" and "betweenness." We do not use these measures because the network in this study is composed of numerous different-sized subnetworks, as shown in Panel A of Table 2. It is difficult to evaluate the centrality of nodes belonging to different-sized subnetworks by using these measures.

12 See Appendix 1 for the mathematical definition of the clustering coefficient.

13 The clustering coefficient cannot be defined for nodes with one degree. Therefore, we treated the value of the clustering coefficient of such nodes as zero. 
"Assortativity coefficient" is the Pearson correlation coefficient of degrees of node linked to each other, which measures the properties of assortative mixing or disassortative mixing ${ }^{14}$. The former is the property that nodes with high degree are more likely to form connections with nodes with high degree, and the latter is that nodes with high degree are more likely to form connections with nodes with low degree. In Panel B, we can confirm the positive values of assortativity coefficient in both 1926 and 1931, which indicates assortative mixing. Namely, banks with high degree are more likely to be connected with banks with high degree. Furthermore, we also check the property of assortative mixing, or not, as the case may be, using a measure of "Average nearest neighbor degree," defined as

$$
K_{n n}(k)=\sum_{k^{\prime}} k^{\prime} P\left(k^{\prime} \mid k\right)
$$

$\mathrm{P}\left(k^{\prime} \mid k\right)$ represents the probability that a neighbor node (adjacent node) of a node with degree $k$ has degree $k^{\prime}$. When $K_{\mathrm{nn}}(k)$ increases (decreases) with $k$, the property of a network is assortative (disassortative). Figure 1 shows the plots of $K_{n n}(k)$ for both of the networks for years 1926 and 1931, and confirms that both of them have a tendency to increase with $k$, which suggests that the network of director interlocking in prewar Japan was assortative. These results are consistent with other studies on the network structure of director interlocking, which generally report assortative mixing of their networks (Battiston and Catanzaro 2004; Conyon and Muldoon 2006) ${ }^{15}$. In Panel B of Table 2, we show the average nearest neighbor degree with respect to individual banks,

\footnotetext{
14 See Appendix 1 for the mathematical definition of the degree correlation.

15 Newman (2001) investigates various networks and finds that social networks generally have a property of assortative mixing, while technological and biological networks have a property of disassortative mixing.
} 
namely, the average of the number of connections for all adjacent banks to a bank ${ }^{16}$. We use this measure in the analyses below.

To illustrate the regional characteristics of interbank networks, in Panel $\mathrm{C}$ we classify banks with connections based on another criterion. A bank with an "intraregional network" is one connected only with banks operating in the same prefecture ${ }^{17}$. By contrast, a bank with an "interregional network" is a bank with at least one connection with a bank whose headquarters were located in a different prefecture. Panel $\mathrm{C}$ indicates that about $70 \%$ of banks were part of an intraregional network in both 1926 and 1931. Thus, the networks of director interlocking were mainly formed within prefectures.

Table 3 reports basic statistics on the financial performance of banks both within and outside networks. A comparison of these two types of banks reveals that large banks had a tendency to have connections with other banks. Further, banks within networks were more profitable and more liquid than banks outside networks. This might reflect the fact that larger banks were more profitable than smaller ones in prewar Japan (Okazaki et al. 2005; etc.).

It is noteworthy that our data allow us to measure the quality of bank networks. We measure the quality of the network of a bank, Bank A, for instance, by the average performance of the banks with which Bank A was connected. Figure 2 shows the distribution of the quality of the networks for the 587 connected banks in 1926 and the 271 connected banks in 1931, respectively. Network quality varies substantially, in

16 This measure was also used in Imakubo and Soejima (2010) to examine the property of affinity in Japan's interbank money market. They regressed the average nearest neighbor degree of each bank on its degree and found a negative correlation, which indicates disassortative mixing. We conducted the same test, and confirmed a positive correlation, which suggested assortative mixing.

${ }_{17}$ Operating in the same prefecture means that the headquarters of both banks were in the same prefecture. 
terms of all financial ratios. In other words, there was substantial heterogeneity in the quality of networks. This fact is significant when considering the implications of interbank networks. For example, a bank connected with banks that were performing well might expect support in times of emergency, and might also expect to share useful information and knowledge. By contrast, a bank connected with banks that were performing badly might be adversely affected as a result. This issue is addressed in the next section.

\section{Networks and Bank Performance}

\subsection{The Effects of Networks on Survivability}

As revealed in the previous section, many banks formed networks through director interlocking in prewar Japan. In this section, we examine how those networks affected bank performance and, thereby, the stability/instability of the financial system. During the 1920s and 1930s, there were many bank failures in Japan because of a sequence of financial crises such as the Showa Financial Crisis (1927) and the Showa Depression(1930-1931). Thus, we explore the relationship between interbank networks and the probability of bank failure. To this end, we construct panel data composed of two sets of cross-sectional data. The first data set (the group for 1926) is the one that relates the interbank network of 1926 to the probability of bank failures between 1927 and 1931 . The second data set (the group for 1931) is the one that relates the interbank network of 1931 to the probability of bank failures between 1932 and 1936.

Using this panel data, we estimate the following probit equation for bank i in year $\mathrm{t}(\mathrm{t}=26,31)$.

$\operatorname{Pr}\left(\mathrm{FAIL}_{\mathrm{it}}=1\right)=\mathrm{F}\left(\alpha_{0}+\alpha_{1} * \mathrm{NETWORK}_{\mathrm{it}}+\alpha_{2}{ }^{*} \mathrm{EQ}_{\mathrm{it}}+\alpha_{3} * \mathrm{SIZE}_{\mathrm{it}}+\alpha_{4} * \mathrm{BOJ}_{\mathrm{it}}+\alpha_{5}{ }^{*} \mathrm{MS}_{\mathrm{it}}\right)$ 
FAIL it is a dummy variable that takes a value of unity if a bank exited because of failure in the following five years, namely between 1927 and 1931 in the case of 1926 and between 1932 and 1936 in the case of 1931, and zero otherwise ${ }^{18}$. As for the explanatory variables, NETWORK is the network variable to capture the effect of interbank networks. In the estimation, we use two alternative sets of variables for NETWORK, namely NT and N_CONNECTION. NT is a dummy variable that equals unity if bank i had at least one connection with another bank, and zero otherwise. N_CONNECTION represents the number of connections. This is to capture the effect of the scale of a network. An interbank network may affect the survivability of a bank in various ways. First, a bank with a network may receive relief loans from its connected banks in the event of an emergency ${ }^{19}$. Second, a bank with a network may be able to share information and useful knowledge, or monitor business relationships that enhance its survivability (Preffer and Salanik 1978; Loderer and Peyer 2002). Hence, in equation (2), the expected sign of the coefficients of NT and N_CONNECTION is negative.

A number of control variables are included in equation (2), following Okazaki et al. (2007) and Okazaki (2007), who investigated the determinants and implications of bank exits in prewar Japan ${ }^{20}$. EQ is used to control for the effect of the Great Kanto Earthquake of 1923. Many banks in the South Kanto District (comprising Tokyo, Kanagawa, Chiba, and Saitama Prefectures) experienced serious bad-loan problems

18 The definition of a failure in the analysis is an exit due to reasons other than a merger, following Okazaki (2007) and Okazaki et al. (2007).

19 Imuta (1980) cites the history of the Shikoku bank, and points out that banks belonging to large networks may have benefited from efficient asset portfolio allocation because they expected to be able to obtain relief loans in times of emergency from banks in their networks.

20 Since the work of Okazaki et al. (2007), and particularly because of their focus on the effects of connections between banks and nonbanking companies, it has been standard practice to include variables relating to these connections in empirical models. In this paper, the model replaces this variable with one designed to capture the effect of interbank networks. 
because of the collateral destruction caused by the earthquake. EQ is a dummy variable that is unity if the bank's headquarters was located in Tokyo, Kanagawa, Chiba, or Saitama Prefectures, and zero otherwise. We expect banks operating in those prefectures to have had higher failure rates. Hence, the coefficient of EQ is expected to be positive. SIZE is defined as the log of total assets ${ }^{21}$. It is likely that large banks can more easily diversify their assets, and are better able to endure negative shocks. Hence, the coefficient of SIZE is expected to be negative. The variable BOJ is a dummy variable that equals unity if a bank had a transaction relationship with the Bank of Japan (BOJ), and zero otherwise. Okazaki (2007) investigated the role of the Lender of Last Resort (LLR) in prewar Japan and found that having a transaction relationship with the BOJ lowered the probability of failure for solvent banks. Hence, the variable BOJ is included to capture the effect of LLR loans. MS denotes the market share of the top three banks in a prefecture in terms of the number of operating units (i.e., the headquarters and branches in the prefecture)22. Because banks in competitive markets are more likely to fail than those in less competitive markets, the coefficient of MS is expected to be negative.

In addition to these control variables, we add several financial ratios of banks. These include the return on equity (ROE), the ratio of capital to deposits (CAPDEPO), the ratio of bank deposit reserves to total assets (LIQUID), and the ratio of security holdings to loans (SECURITY), following Okazaki et al. (2007) and Okazaki (2007). These variables were chosen primarily to capture the components of the CAMEL rating, which has become a standard indicator of the risk of bank failure (Wheelock and Wilson 2000). CAPDEPO is used to capture the capital adequacy of a bank. A low value for this

21 Total assets are the sum of total capital and total deposits.

22 This variable is common for all banks in the same prefecture. Because data on the amounts of deposits or loans of individual banks by prefecture are not available, we used the number of branch offices to represent market share. 
variable indicates a high risk. LIQUID is used to capture the liquidity of assets. If a bank has sufficient liquid assets, it is likely to survive an abrupt withdrawal of deposits. An increase in ROE is expected to reduce the probability of bank failure. Note that the profit data on individual banks used to measure ROE are censored at zero by our source (Ginkokyoku Nenpo). That is, bank losses (negative profits) are not reported by this source $^{23}$. Then, in the following analyses, the values of ROE in those banks are treated as zero. SECURITY is used to capture the risk associated with asset portfolios. In existing studies of the banking industry in prewar Japan, securities are treated as relatively safe assets with lower risks. This is because these securities comprise mainly government bonds and corporate bonds issued by major companies (Nanjo and Kauya 2006). Hence, we expect the coefficient of SECURITY to be negative. With respect to all explanatory variables, the values of the end of 1926 and 1931 are used in the cases for the 1926 and 1931 groups, respectively. In addition, the dummy variable for the group of the relevant year is included in the estimation.

Table 4 reports the estimation results of equation (2). In columns 1 and 2, we use NT as a network variable. In column 1, the coefficient of NT is negative and statistically significant at the $1 \%$ level, which suggests that banks within networks were less likely to fail than those outside networks. Hence, interbank networks through director interlocking had a positive effect on survivability of banks. The coefficients of SIZE, EQ, and MS are statistically significant and have the expected signs. Thus, smaller banks in more competitive markets or those in areas damaged by the Great Kanto Earthquake in 1923 were more likely to fail. This finding is consistent with those of Okazaki et al. (2007) and Okazaki (2007). In column 2, the financial ratio variables are added. We can confirm that ROE has an especially strong effect: the coefficient of ROE is negative and

23 The percentage of banks with censored observations is 10.4 . 
statistically significant at the $1 \%$ level. This indicates that profitable banks were less likely to exit because of failure. After controlling for the financial ratios, the coefficient of NT remains negative and statistically significant at the $1 \%$ level. This result is inconsistent with a series of studies that suggest that board interlocks negatively affected firm value (Fich and Shivdasani 2006; Non and Franses 2007; Devos et al. 2009; Croci and Grassi 2010; etc.). One interpretation of the above estimation results is that a bank connected with banks that were performing well could expect support in times of emergency, or could expect to share useful information and knowledge or to monitor business relationships (Preffer and Salanik 1978; Loderer and Peyer 2002).

In columns 3, we use the number of connections (N_CONNECTION) as a network variable. In column 3, the coefficient of N_CONNECTION is negative and statistically significant at the $5 \%$ level, which suggests that the more connections a bank had with other banks, the less likely it was to fail. The variable N_CONNECTION corresponds to "degree centrality" in network measures. Therefore, this result is completely different from that of Croci and Grassi (2010), who find that network centrality negatively affects firm performance, using data on Italian firms. Furthermore, in column 4, we replace it with the four dummy variables indicating the number of connections, considering the nonlinear effect of the network. For instance, Dummy [N_CONNECTION=1] takes a value of unity if a bank had one connection with another bank, and zero otherwise. It can be confirmed in column 4 that all dummy variables have negative coefficients, and that the negative effects are statistically significant when banks have either one connection or four or more connections. Therefore, the effect of the network on bank survivability is not a simple linear relation. On the other hand, the banks with four or more connections were less likely to fail, which implies that banks with high centrality enjoyed substantial benefits from the network. Therefore, it is worth examining the effect of network structure on bank survivability in more detail. We will consider this point later. 


\subsection{Endogeneity of Interbank Networks}

In the preceding analysis, network variables were treated as exogenous. However, we cannot a priori deny the possibility that interbank networks were formed endogenously. For example, a bank may want to form networking links with a bank that is performing well because the former expects the latter to bring future benefits. If so, a bank that is performing well has more chance of having networks with other banks, which makes network variables endogenous. Hence, to control for the potential endogeneity of interbank networks, we consider the following equation, which includes two instrumental variables for the network variable NETWORK:

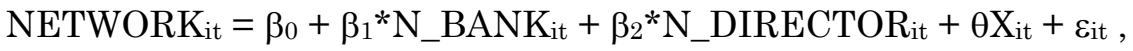

where the dependent variable NETWORK denotes the network variables. The explanatory variable N_BANK denotes the total number of banks in the prefecture where a bank operated. We employ this variable as an instrument for the network variable. This is justifiable because, as shown in Panel C of Table 2, interbank networks developed mainly within the same prefecture and, hence, a bank in the prefecture where there were many banks was more likely to have a connection with another bank. Hence, the coefficient of N_BANK is expected to be positive. N_DIRECTOR is the number of directors working for the bank in 1926 or 1931. Because our measure of networking is director interlocking, the more directors a bank had, the more likely it was for that bank to have had a network with other banks. Hence, the coefficient of N_DIRECTOR is expected to be positive ${ }^{24}$. X represents a vector of exogenous variables. When NT is used

24 The literature on corporate governance shows that the number of directors is correlated with firm performance. For example, Yermack (1996) showed that firms with fewer directors had higher stock market valuations. If the number of bank directors in 1926 was correlated with the ex ante performance of banks (as measured by, say, financial performance or market valuation in 1926), we cannot deny the possibility of a 
as NETWORK, we estimate equation (3) as a bivariate probit model because NT is a binary variable ${ }^{25}$. That is, we estimate equations (2) and (3) simultaneously. On the other hand, when N_CONNECTION is used as NETWORK, we estimate both equations with a two-stage least squares method (Newey 1987). The estimation results of equations (2) and (3) are presented in columns 1, 3, and 5 and in columns 2, 4, and 6 of Table 5, respectively. In column 1 (Model 1), as before, the coefficient of NT is negative and statistically significant at the $1 \%$ level, even after controlling for the endogeneity of interbank networks. In column 2 (Model 1), both instrumental variables (N_BANK and N_DIRECTOR) have the expected signs and statistically significant effects. In columns 3 and 4 (Model 2), where financial ratios are included as explanatory variables, the coefficient of NT is negative and statistically significant at the $1 \%$ level. Hence, we have strong evidence that interbank networks had a positive effect on bank survivability, even after controlling for the endogeneity of interbank networks. In columns 5 and 6 (Model 3), where the number of connections (N_CONNECTION) is used as an endogenous variable, the coefficient of N_CONNECTION is negative and statistically significant at the $1 \%$ level. In summary, having controlled for the endogeneity of interbank networking, we obtained robust evidence that interbank networking through director interlocking had a positive effect on bank survivability.

correlation between the number of bank directors in 1926 (1931) and the ex post performance of banks, namely, the probability of bank failure between 1927 and 1931 (1932 and 1936). Therefore, we checked whether the number of directors in 1926 (1931) affected financial performance (profitability and solvency risk) in 1926 (1931). Because stock price data are available only for a small number of banks, in this analysis, we used returns on equity and the ratio of capital to deposits as indicators of profitability and solvency risk, respectively. However, our results confirm that the number of directors rarely affected the financial performance of banks significantly. Therefore, the number of directors was likely to be uncorrelated with, at least, the ex ante performance of banks.

${ }^{25}$ In a probit model incorporating instrumental variables that are estimated by maximum likelihood estimation, or by the minimum chi-squared two-step procedure proposed by Newey (1987), it is assumed that the endogenous variables are continuous. Hence, these models are not appropriate when the endogenous variables are binary. 


\subsection{The Effect of Network Structure and Quality on Survivability}

Next, we investigate the effect of the structure and quality of the network on bank survivability. In Table 6 , we focus on the effect of the network structure. In the estimation, we add the interaction term between NT and network measures used in Table 2 to the explanatory variables in equation (2). In columns 1 and 2 of Table 6 , we use "core degree" and "clustering coefficient," respectively, as a network measure. In the estimation, we use the value of clustering coefficient plus one to distinguish between a bank without connections and one whose clustering coefficient value is zero. It can be confirmed from columns 1 and 2 that the interaction terms between NT and these network measure variables are negative, which suggests that banks that belonged to high-density subnetworks were less likely to fail. However, these coefficients are not statistically significant. In column 3, "average nearest neighbor degree" is used as a network measure variable. This interaction term is negative and statistically significant at the $10 \%$ level, which indicates that banks connected with banks having many connections were less likely to fail. In column 4, as a network measure, we use "size of component," which represents the number of nodes (banks) in the component to which a bank belongs. The coefficient of its interaction term is negative, but not significant. Hence, the size of the network to which a bank belonged did not matter. In column 5 , we use a dummy variable that takes a value of unity if a bank belongs to intraregional networks defined in Panel $\mathrm{C}$ of Table 2, and zero otherwise. As shown in column 5, the interaction term of the dummy variable for intraregional networks does not have a significant coefficient, which suggests that regional characteristics of network structure did not affect bank survivability.

In Table 7, we examine the implications of network quality. It is hypothesized that a bank that had connections with banks that were performing well would be more likely to survive than banks with no such connections. To capture the quality of the network, 
we add to equation (2) the interaction term $\mathrm{NT} * \mathrm{WA}(\mathrm{ROE})$, where WA(ROE) denotes the weighted average ROE of the connected banks. Column 1 reports the estimation results. Although the coefficient of NT is no longer negative, the coefficient of $\mathrm{NT}^{*} \mathrm{WA}(\mathrm{ROE})$ is negative and statistically significant at the $1 \%$ level, which is consistent with our hypothesis. That is, banks that had connections with profitable banks were less likely to fail.

However, given that values of ROE are censored at zero because of the data limitations mentioned above, the coefficient of the interaction term $\mathrm{NT}^{*} \mathrm{WA}(\mathrm{ROE})$ may be biased. To check the robustness of the results, we split NT into two dummy variables, NTP and NTN, according to the ROE of connected banks. That is, NTP is unity if the values of ROE are positive for all connected banks, and NTN equals unity if ROE was not positive for at least one of the connected banks. We then add NTP, NTN, and NTP*WA(ROE) to equation (2). By using the new interaction term NTP*WA(ROE), the effect of network quality is estimated more accurately. Column 2 reports the estimation results. The coefficient of the interaction term $\mathrm{NTP}^{*} \mathrm{WA}(\mathrm{ROE})$ is negative and statistically significant at the $5 \%$ level. It is slightly larger than the coefficient of $\mathrm{NT}^{*} \mathrm{WA}(\mathrm{ROE})$ in column 1 . We can calculate the marginal effects based on these estimates. According to our calculation, a 1\% increase in the weighted average ROE of its connected banks lowers the probability of a bank's failure by $0.80 \%^{26}$. In this sense, banks benefited when connected to banks that were performing well.

To examine the effect of having a network with a badly performing bank, in column 3 we present estimates based on slightly different definitions of NTP and NTN. That is, we let NTN equal unity if ROE is not positive for all connected banks, and we let NTP equal unity if at least one connected bank has a positive ROE. As shown in column

${ }^{26}$ We calculated it from the marginal effect where all explanatory variables are evaluated at their means. 
3, the coefficient of NTN is positive, which indicates that banks connected to badly performing banks were more likely to fail. However, this coefficient is statistically insignificant. In other words, we find no clear evidence that banks were adversely affected by being connected to badly performing banks.

In summary, most of the variables about network measures did not have statistically significant effects, as shown in Table 6. On the other hand, we obtained strong evidence that banks that had connections with profitable banks were less likely to fail. Therefore, we can conclude that the quality of the network was more important for survivability of a bank than the structure of the network.

\section{Bank Networks and the Contagious Withdrawal of Deposits}

We now examine the effect of interbank networks on the ability of banks to collect deposits. As discussed in existing studies, it is possible that financial contagion spreads through interbank networks (Allen and Gale 2000; Freixas et al. 2000). For instance, if a bank closes because there is a run on that bank, the banks connected with it are more likely to be exposed to contagious runs. This is because depositors would suspect that connected banks would become insolvent and illiquid because of the closed bank's defaults on its interbank loans. There is well-known anecdotal evidence that this occurred during Japan's financial crisis of 1927 (the Showa Financial Crisis)27. Thus, we examine whether this type of contagious withdrawal of deposits occurred in prewar Japan. For this purpose, we estimate the following equation for the growth of deposits:

GDEPO $_{\mathrm{i}}=\gamma_{0}+\gamma_{1} * \mathrm{NT}_{\mathrm{i}}+\gamma_{2} * \mathrm{NT}_{\mathrm{i}} * \mathrm{WA}(\mathrm{GDEPO})_{\mathrm{i}}+\gamma_{3}{ }^{*} \mathrm{M}_{\mathrm{A}} \mathrm{A}_{\mathrm{i}}+\gamma_{4}{ }^{*} \mathrm{SIZE}_{\mathrm{i}}+\gamma_{5}{ }^{*} \mathrm{CAPDEPO}_{\mathrm{i}}$

27 At the beginning of the Showa Financial Crisis of 1927, the run on the Tokyo Watanabe Bank immediately triggered a run on its family bank, the Akaji Savings Bank. Consequently, these two banks closed. 


$$
+\gamma_{6}{ }^{*} \text { LIQUID }_{i}+\gamma_{7} * \text { ROE }_{i}+\gamma_{8}{ }^{*} \text { SECURITY }_{i}+u_{i}
$$

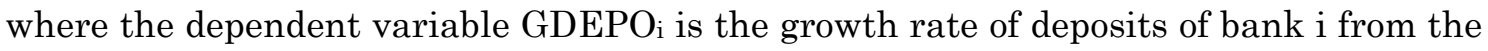
end of 1926 to the end of 1927. This period includes the Showa Financial Crisis of 1927, when nationwide bank runs led to the closure of 44 banks. In equation (4), the interaction term $\mathrm{NT}_{\mathrm{i}}{ }^{*} \mathrm{WA}(\mathrm{GDEPO})_{\mathrm{i}}$ is used to capture the contagious effect of the deposits shock on the banks that had connections with bank i. The variable WA(GDEPO) is the weighted average growth rate of deposits of the banks connected with bank i. If the deposits of a bank fell because of withdrawals from banks in the same network, the coefficient on $\mathrm{NT}_{\mathrm{i}}{ }^{*} \mathrm{WA}(\mathrm{GDEPO})_{\mathrm{i}}$ would be positive. In addition, given that the effect of positive growth of deposits of connected banks is not necessarily linear, we also estimate equation (4) by replacing $\mathrm{NT}_{\mathrm{i}}$ and $\mathrm{NT}_{\mathrm{i}}{ }^{*} \mathrm{WA}(\mathrm{GDEPO})_{\mathrm{i}}$ with $\mathrm{NTP}_{\mathrm{i}}$ and $\mathrm{NTN}_{\mathrm{i}}$, respectively. The dummy variable $\mathrm{NTP}_{\mathrm{i}}$ is unity if the weighted average growth rate of deposits of the banks connected with bank $i$, is positive, and zero otherwise. The variable $\mathrm{NTN}_{\mathrm{i}}$ is a dummy variable that is unity if the weighted average growth rate of deposits of the connected banks is negative, and zero otherwise. If the deposits of a bank fell because of contagious withdrawals from within the same network, the coefficient of $\mathrm{NTN}_{\mathrm{i}}$ would be negative. The dummy variable M\&A is unity if a bank experienced mergers or acquisitions in 1927, and zero otherwise. For banks that experienced mergers or acquisitions in 1927, to calculate GDEPO, we use the deposits of 1926 for the pro forma banks ${ }^{28}$. In addition, measures of bank size and the financial ratios used in equation (2) are included as explanatory variables. We also include area dummies to

28 The value of a pro forma bank denotes the combined values of the balance sheets of participating banks. With respect to other variables, the values of acquiring banks are used. 
control for area-specific shocks ${ }^{29}$. Our sample size is reduced by 183 (out of 1,007 ) because of bank exits. In addition, we excluded eight banks classed as outliers because the growth rate of their deposits exceeded 100\%. This left 816 observations for estimation.

Table 8 shows the estimation results. In column 1, the coefficient of $\mathrm{NT}^{*} \mathrm{WA}(\mathrm{GDEPO})$ is positive, which is consistent with the contagious withdrawals of deposits. However, the coefficient is not statistically significant. In column 2 , the area dummies are excluded to account for the possibility that the area dummies capture the contagious effect of networks. However, as shown in column 2, the coefficient of $\mathrm{NT}$ *WA(GDEPO) is statistically insignificant, as before, but is slightly larger than before. Thus, we find no strong evidence of the contagious withdrawal of deposits within networks.

In column 3, to examine the contagion effect, we use NTN and NTP as the network variables. The coefficient of NTN is negative, which is consistent with the contagious withdrawals of deposits. However, this effect is not statistically significant. In addition, although the coefficient of NTP is positive, it is not statistically significant. In column 4, which excludes area dummies, the coefficient of NTN is positive, which is inconsistent with the contagious withdrawals of deposits. However, the coefficient of NTP is positive and statistically significant at the $10 \%$ level, which suggests that banks with connections to banks whose deposits increased were capable of collecting more deposits.

The coefficients of ROE and CAPDEPO are positive and statistically significant, which implies that banks performing well were more likely to collect deposits. In other words, fundamental factors explain deposits growth better than do contagious factors.

${ }^{29}$ We split the whole country into 10 areas: Hokkaido/Tohoku, North Kanto, South Kanto, Tokyo, Chubu/Hokuriku, Tokai, Osaka/Hyogo, other Kansai, Chugoku/Shikoku, and Kyushu/Okinawa. 
This is consistent with the findings of Yabushita and Inoue (1993) and Okazaki (2007), who examined the factors affecting the probability of bank closures during the Showa Financial Crisis of 1927. They found that fundamental factors, including profitability, principally explain the probability of bank failures. In summary, there is no strong evidence for the contagious effect of interbank networks.

Next, we check the robustness of the results. First, we correct for the potential endogeneity of interbank networks, as in Subsection 3.2. Again, we use N_BANK and N_DIRECTOR as instruments for the network variables. We show the instrumental variable regressions in columns $5-8$. These results show that, having controlled for the endogeneity of interbank networks, the coefficients of WA(GDEPO) and NTN are statistically insignificant.

Second, to correct for the potential selection bias arising from bank exits, we estimate equation (4) by employing the sample selection model. In this model, the selection equation explains the probability of exit, and includes as explanatory variables SIZE, EQ, BOJ, MS, CAPDEPO, LIQUID, ROE, and SECURITY, which are the variables used in equation (2). We report the estimation results for the main equation in Appendix Table 1. After correcting for potential sample selection bias, the coefficients of WA(GDEPO) and NTN are statistically insignificant.

\section{Bank Networks and Consolidation}

As mentioned above, a large wave of bank consolidations occurred in Japan in the late 1920s and early 1930s after the implementation of the Bank Law of 1927 . This law prescribed that a bank should, in principle, have capital of no less than one million yen, and that an existing bank whose capital was less than this was required to meet this 
requirement within five years ${ }^{30}$. Although more than half of the ordinary banks did not meet this criterion when the law was enacted in 1928, none of these smaller banks was allowed to increase its capital in principle. Therefore, these banks were obliged to implement consolidations or liquidations. Thus, in this section, we address the question of how interbank networks were related to the process and results of these consolidations.

\subsection{Bank Networks and Choice of Merger Partners}

First, we examine the effects of interbank networks through director interlocking on the process of consolidations. Most banks whose capital was below the minimum requirement searched for consolidation counterparts in order to avoid liquidation. How did these banks choose their counterparts? What role did the networks play in the process? It is possible that interbank networks affected the choice of counterparts. For instance, a bank might have been uncertain about the soundness of another bank that was a potential candidate for a merger because of informational asymmetry. In this case, an interbank network based on director interlocking might have mitigated such information asymmetry between the two banks and, thereby, resolved the adverse selection problem. Moreover, directors serving both banks might have been able to coordinate negotiations over consolidation to reduce transaction costs ${ }^{31}$. Therefore, one would expect banks to be more likely to be consolidated with banks in the same network than with those outside the network.

${ }^{30}$ According to the 1927 Bank Law, in principle, a bank should have capital of at least one million yen, and an existing bank whose capital was less than this was required to meet this requirement within five years. If the headquarters of the bank was located in Tokyo or Osaka, the minimum capital was two million yen, while it was 500,000 yen if the headquarters was located in a town or village whose population was at least 10,000. ${ }^{31}$ D'aveni and Kesner (1993) show that target firms are less likely to resist a takeover when their managers and the acquiring firm's outsiders have shared connections to the same prestigious networks. 
The information on each bank merger is obtained from Ginko Jiko Geppo (Monthly Bank Affairs) edited by the BOJ. From this information, we can identify which of the 1,007 sample banks participated in consolidations between January 1927 and December 1929, and which bank was a counterpart. Table 9 compares the proportion of banks within networks in the total number of merged banks with the proportion of banks within networks in the total number of banks that were not merged. This comparison reveals that the proportion of banks within networks was significantly larger among merged banks. This suggests that interbank networks had a significant positive effect on bank mergers.

We test this hypothesis by using data on the events of individual bank consolidations that occurred between January 1927 and December 1929. From the consolidation events reported in Ginko Jiko Geppo, we selected those for which information on the directors involved was available for all participating banks. This yielded information on 173 events. Table 10 shows the number and proportion of intranetwork consolidations in which the participating banks were connected with each other before the consolidation. In cases in which the number of participating banks was more than two, an event was regarded as an intranetwork consolidation if there had been at least one connection among the participants. In Panel A, consolidations are classified into three categories according to Ginko Jiko Geppo: absorption, acquisition, and combination into a new bank. In this context, combination into a new bank is a form of consolidation under which a new bank is established after the dissolution of all participants.

In more than $30 \%$ of the consolidations, networks already existed among the participating banks. By observing the different types of consolidations, we found that the proportion of intranetwork consolidations in the "combination into a new bank" category was approximately double the proportion in the other categories. In addition, 
Panel B distinguishes between "one-to-one consolidation" and "more than two consolidations" with respect to the number of participating banks. These results indicate that this proportion is higher in the "more than two consolidations" case than in the "one-to-one consolidation" case.

In interpreting the above findings, we use Kin'yu Kenkyu-Kai (1934), which comprehensively surveyed bank consolidations in Japan in this period, as a basic reference. According to this reference, participant banks tended to combine into a new bank when the banks were equally powerful. However, in general, negotiations over consolidations are thought to be more likely to fail when many equally powerful participants are involved. Integrating these points into the results in Table 10, our interpretation is that interbank networks facilitated coordination among merger participants, particularly when negotiation costs were high.

Panel C classifies consolidations into intraregional consolidations and interregional consolidations. Whereas the former refers to consolidations in which all participating banks operated in the same prefecture, the latter refers to other consolidations. Panel $\mathrm{C}$ shows that intranetwork consolidations were more common among intraregional consolidations than among interregional consolidations.

Panel D classifies consolidations into policy-promoted consolidations and strategic consolidations, following Okazaki and Sawada (2007). That is, we first classified banks into those that met the minimum capital criterion of the 1927 Bank Law and those that did not. Then, we classified a consolidation that involved at least one participating bank not meeting the minimum capital criterion as a policy-promoted consolidation, and we classified a consolidation in which all the participants met the criterion as a strategic 
consolidation $^{32}$. Panel D shows that intranetwork consolidations were more common among strategic consolidations than among policy-promoted consolidations. We expect the negotiation costs incurred in strategic consolidations to exceed those incurred in policy-promoted consolidations. This is because, in strategic consolidations, a bank meeting the minimum capital criterion of the 1927 law had no need to merge with another bank in the event that the participants were unable to agree on merger terms. Hence, one can infer that interbank networks facilitated coordination among merger participants when negotiation costs were high.

The results reported in Panels $\mathrm{A}$ and $\mathrm{C}$ must be interpreted with care. In the context of Panel A, it is possible that participating banks were more likely to have connections among themselves when combining into a new bank, simply because the number of participants was larger in this case. In the context of the results in Panel C, intranetwork consolidations were more common among intraregional consolidations simply because the density of networks was higher within the same prefecture, as we showed in Section 2.

Thus, it is necessary to examine the role of interbank networks in determining merger partners, controlling for these other factors. Thus, using the data on 320 banks that participated in 173 consolidations that occurred from 1927 to 1929 , we tested whether a connection between a pair of banks raised the probability of consolidation between them. The equation to be estimated is as follows:

$\operatorname{Pr}\left(\operatorname{MERGE}_{\mathrm{ij}}=1\right)=\mathrm{F}\left(\beta_{0}+\beta_{1} * \mathrm{NT}_{\mathrm{ij}}+\beta_{2} * \mathrm{PREF}_{\mathrm{ij}}\right), \mathrm{i} \neq \mathrm{j}$,

32 The information on the addresses of the headquarters was obtained from Ginko Soran (The Comprehensive List of Banks). We obtained the information on the population of the city, town, or village in which the headquarters of each bank was located from Nippon Teikoku Tokei Nenkan (Statistical Year Book of the Japanese Empire). 
where MERGE $\mathrm{i}_{\mathrm{j}}$ is a dummy variable that is unity if bank $\mathrm{i}$ and bank $\mathrm{j}$ merged between 1927 and 1929, and zero otherwise. The $\mathrm{NT}_{\mathrm{ij}}$ dummy variable is unity if there was director interlocking between bank $\mathrm{i}$ and bank $\mathrm{j}$ in 1926, and zero otherwise. A positive coefficient of $\mathrm{NT}_{\mathrm{ij}}$ suggests that a network between the two banks made it easier for them to merge. The dummy variable $\mathrm{PREF}_{\mathrm{ij}}$ is unity if the headquarters of banks $\mathrm{i}$ and $\mathrm{j}$ were located in the same prefecture, and zero otherwise. We estimated equation (5) as a logit model for all possible pairs of banks ${ }^{33}$.

The estimation results are reported in Table 11 . The result in column 1 is for the full sample of consolidation observations. The coefficient of NT is positive and statistically significant, which suggests that banks preferred to merge with banks with which they were already connected. In columns $2-4$, the consolidations are classified into absorptions, acquisitions, and combinations into a new bank, respectively. Although the coefficient of NT is positive and statistically significant in all cases, it is larger for combinations into new banks, which is consistent with the results in Panel A of Table 10. Hence, it can be concluded that interbank networks facilitated coordination among merger participants, particularly when negotiation costs were high.

In Panel $\mathrm{B}$, consolidations are classified into intraregional and interregional consolidations. The explanatory variable $\mathrm{PREF}_{\mathrm{ij}}$ is excluded. The coefficient of NT is positive and statistically significant for both intraregional and interregional consolidations, with the former being larger, which is consistent with the results in Panel C of Table 10.

In Panel $\mathrm{C}$, consolidations are classified into policy-promoted and strategic consolidations. The coefficient of NT is positive and statistically significant for both

33 The total number of pairs of banks $\mathrm{i}$ and $\mathrm{j}$ is $\mathrm{N}^{*}(\mathrm{~N}-1) / 2$ after removing pairings of the same bank. Therefore, among 320 banks, there are 51,040 pairs. 
policy-promoted and strategic consolidations, with the latter being larger. This indicates that networks played a more important role in strategic consolidations.

In summary, interbank networks facilitated consolidation with other banks, and were more important in consolidations in which negotiation costs were high.

\subsection{Bank Networks and Post-merger Performance}

We have presented evidence that interbank networks facilitated consolidations within networks. How, then, did interbank networks affect the results of the consolidations? To be more specific, did intranetwork consolidations have a more positive effect on bank performance than other consolidations? For example, did networks reduce the costs of unifying different organizations? To address these issues, we estimate the effects of intranetwork consolidations on post-merger financial performance. We follow the methodology of Okazaki and Sawada (2007), who used data on 1927-1932 events to examine the effect of consolidations promoted by the 1927 Bank Law on the financial performance of banks. These authors estimated the effect of consolidations on bank performance by comparing the change in the return on assets (ROA) and the change in the growth rate of deposits from year $\mathrm{T}-1$ to years $\mathrm{T}+2$ and $\mathrm{T}+3$ between consolidated banks and nonconsolidated banks, with $\mathrm{T}$ being the year in which the consolidation occurred ${ }^{34}$. In our analysis, we focus on consolidation events from 1927 to 1929 .

First, we select consolidation events. To identify clearly the effects of consolidation, we exclude from the analysis banks that participated in multiple consolidations from the beginning of year $\mathrm{T}-1$ to the end of year $\mathrm{T}+3^{35}$. In addition, we limit our attention to

${ }^{34}$ Furthermore, to capture the effect of policy-promoted consolidations, the authors split the effect of consolidations into a policy-promoted effect and a strategic effect.

$35 \mathrm{We}$ include in these events cases in which one bank merges with other banks twice in the same year, and we treat these consolidations as single instances of merger. There 
consolidation events for which data on director interlocking were available for all participating banks. This yielded information on 66 consolidation events. Next, we select the control samples for each year (1927-1929) for comparison with the consolidated banks. The control sample banks, which correspond to the consolidated banks in year T, refer to the banks that were not involved in any consolidations from the beginning of year $\mathrm{T}-1$ to the end of year $\mathrm{T}+3$. For example, the control samples for 1927 are the banks that were not involved in any consolidations from 1926 to 1930. These are compared with the banks that were consolidated in 1927. Event observations for 1927 were the consolidated banks in 1927 and their control sample banks. In the same way, event observations were constructed for 1928 and 1929 to yield unbalanced panel data for three years, 1927, 1928, and 1929, which consist of 1,075 event observations. Table 12 shows the number of consolidations and control samples by year. The consolidations are classified into intranetwork consolidations and other consolidations. Approximately $30 \%$ of the consolidations are classified as intranetwork consolidations, in which the participating banks had a mutual connection through director interlocking.

For our empirical specification, the model of Okazaki and Sawada (2007) was modified slightly to capture explicitly the effects of intranetwork consolidations. That is, we estimated the following model:

$\Delta \mathrm{Y}_{\mathrm{it}}=\lambda_{0}+\lambda_{1} * \mathrm{M} \& \mathrm{~A}_{\mathrm{it}}+\lambda_{2} * \mathrm{NT}_{\mathrm{it}} * \mathrm{M} \& \mathrm{~A}_{\mathrm{it}}+\theta \mathrm{X}_{\mathrm{it}}+\varepsilon_{\mathrm{it}}$,

where $\mathrm{i}$ indexes the bank, and $\mathrm{t}$ indexes the year. The dependent variable $\Delta \mathrm{Y}_{\text {it }}$ is the change in either the ROA or the growth rate of deposits from the end of year T-2 to the

were four such cases: Dai-Hachiju-go Bank (1927); Juni Bank (1928); Ogaki Kyoritsu Bank (1928); and Gojuroku Bank (1928). 
end of year $\mathrm{T}+2$ or $\mathrm{T}+3^{36}$. For the values of $\mathrm{Y}_{\text {it }}$ for the consolidated banks in year $\mathrm{T}-2$, those of the pro forma banks were used. This means that we used the sum of the balance sheets of the banks participating in consolidations. The explanatory variable M\&A is a dummy variable that is unity if a bank participated in consolidations, and zero otherwise. A positive coefficient of M\&A indicates that consolidation had a positive effect on bank performance. The dummy $\mathrm{NT}^{*} \mathrm{M} \& \mathrm{~A}$ is unity if a bank participated in an intranetwork consolidation in year $\mathrm{T}$, and zero otherwise. A positive coefficient of NT*M\&A indicates that intranetwork consolidations had a more beneficial effect on bank performance than other consolidations. We are particularly interested in the effect of this variable. $\mathrm{X}$ is a vector of additional explanatory variables. Following Okazaki and Sawada (2007), we include the natural log of total assets (SIZE), the change in the number of branch offices $(\triangle \mathrm{BRANCH})$, and the dummy variable URBAN, which indicates whether the headquarters of the bank was located in an urban area (i.e., in Tokyo, Kanagawa, Aichi, Kyoto, Osaka, or Hyogo Prefectures) ${ }^{37}$. In addition, for the model in which the dependent variable is the change in the ROA, the loan-asset ratio (LOAN/ASSET) is included to capture the asset risk of banks. Equation (6) is estimated by pooled OLS with heteroskedasticity robust standard errors (White 1980).

Table 13 reports the estimation results for the model of the growth rate of deposits. Columns 1-4 report results based on the whole sample of banks. The results reported in columns 5-8 are based on excluding outliers, defined as cases in which the growth rate of a bank's deposits exceeded $100 \%$. In columns 1 and 2 , the dependent variable is the growth rate of deposits from the end of year $\mathrm{T}-2$ to the end of year $\mathrm{T}+2$. In columns 3 and

\footnotetext{
36 Because consolidations were frequently accompanied by asset reevaluation, the value of the assets of the post-consolidation bank was adjusted according to the following equation: $A_{S S E T_{T+i}^{*}}^{*}=A S S E T_{T-1}+\left(A S S E T_{T+i}-A S S E T_{T}\right), i=2,3$.

37 The year dummies were also included as explanatory variables to control for shocks common to observations relating to the same year.
} 
4 , the dependent variable is the growth rate of deposits from the end of year T-2 to the end of year $\mathrm{T}+3$. Column 1 reports estimation results based on excluding $\mathrm{NT}{ }^{*} \mathrm{M} \& \mathrm{~A}$. The coefficient of the consolidation dummy (M\&A) is positive and statistically significant. This suggests that consolidations enhanced the ability of banks to collect deposits, which is consistent with the findings of Okazaki and Sawada (2007). In column 2, the variable $\mathrm{NT}^{*} \mathrm{M} \& \mathrm{~A}$ is added to capture the effect of intranetwork consolidations. Although the coefficient of M\&A remains positive and statistically significant, the coefficient of $\mathrm{NT}^{*} \mathrm{M} \& \mathrm{~A}$ is negative but statistically insignificant. This suggests that intranetwork consolidations did not have greater beneficial effects on growth rates of deposits than other consolidations. Columns 3 and 4 report results based on using changes in deposits from $\mathrm{T}-2$ to $\mathrm{T}+3$ as the dependent variable. In column 4 , the coefficient of $\mathrm{NT}^{*} \mathrm{M} \& \mathrm{~A}$ is positive but statistically insignificant. Thus, there is no evidence that the effect of intranetwork consolidations exceeded that of other consolidations. Excluding outliers did not qualitatively change the results (see columns 5-8). In summary, in prewar Japan, consolidation itself had a positive effect on growth rates of deposits, but this positive effect was not significantly larger for intranetwork consolidations.

Table 14 reports the estimation results for equation (6), with the change in the ROA being the dependent variable. Columns 1 and 2 (columns 3 and 4) report results for performance changes from the end of year T-2 to year $\mathrm{T}+2$ (from the end of year T-2 to year $\mathrm{T}+3)$. In columns 1 and 3 , the coefficients of the consolidation dummy (M\&A) are negative but not statistically significant. In columns 2 and 4 , the coefficients of $\mathrm{NT}^{*} \mathrm{M} \& \mathrm{~A}$ are positive and negative, respectively, but not statistically significant. Therefore, there is no clear evidence that intranetwork consolidations had a more beneficial effect on bank profitability than other consolidations.

In columns $5-8$, we report results for equation (6), with the change in the ROA being the dependent variable, taking into account that the profit data are censored at 
zero. Having eliminated from the sample those banks with a recorded profit of zero, we estimated equation (6) by maximum likelihood, correcting for sample selection. Following Okazaki and Sawada (2007), we included in the selection equation the consolidation dummy (M\&A), SIZE, URBAN, LOAN/ASSET, and year dummies, which we expect will explain cross-sectional differences in bank profits. (The estimated selection equation is not reported.) The estimation results for the main equation are reported in columns 5-8. These results provide no evidence that intranetwork consolidation had a more beneficial effect on bank profitability than other consolidations.

In summary, the results obtained in this section indicate that interbank networks facilitated within-network consolidations by reducing the costs of coordination, but that intranetwork consolidations did not strongly enhance post-merger performance.

\section{Concluding Remarks}

This paper investigated the structure and implications of interbank networks, focusing on director interlocking in prewar Japan. It was found that approximately half of the banks had at least one connection with another bank through director interlocking. The structure of the network through director interlocking is revealed to be assortative, relatively low clustered, and composed of numerous components. Next, we examined the impact of interbank networks through director interlocking on the survivability of banks to find that a bank with a network was less likely to fail than a bank without one. Furthermore, a bank that had a network with profitable banks was less likely to fail. On the other hand, the network structure rarely affected bank survivability. In other words, the quality of the network was more important to surviving in the banking industry in 
prewar Japan than the structure of the network. These results suggest that interbank networks through director interlocks contributed to the stability of the financial system.

Furthermore, we examined whether financial contagion spread through interbank networks, considering the possibility that our measure of the network included financial relationships. However, we found no strong evidence of financial contagion through interbank networks.

Finally, the paper found that the networks based on director interlocking also affected bank consolidations, which surged in Japan in the 1920s and 1930s. Banks tended to consolidate with banks that had connections with them through director interlocking. This suggests that interbank networks played a role in coordinating bank mergers. On the other hand, whether banks merged with other banks from inside or outside their networks did not significantly affect their post-merger performance. However, given that bank mergers positively affected deposits (Okazaki and Sawada 2007), interlocking networks of directors contributed to stabilizing the financial system, in the sense that they facilitated bank mergers.

\section{Appendix: The Mathematical Expressions of Network Measures}

\section{A.1 Clustering Coefficient}

The clustering coefficient of each bank is defined as

$$
c_{i}=\frac{2}{k_{i}\left(k_{i}-2\right)} \sum_{j, h} e_{i j} e_{i h} e_{j h}
$$

where $e_{i j}$ is a variable which takes a value of unity if bank $\mathrm{i}$ had a connection with bank $\mathrm{j}$. Also, $e_{i h}\left(e_{j h}\right)$ is a variable which takes a value of unity if bank i $(j)$ had a connection with bank h. $k_{i}$ is the degree of bank i. 


\section{A.2 Degree Correlation Coefficient}

The degree correlation coefficient is defined as

$$
r=\frac{M^{-1} \sum_{i} j_{i} k_{i}-\left[M^{-1} \sum_{i} \frac{1}{2}\left(j_{i}+k_{i}\right)\right]^{2}}{M^{-1} \sum_{i} \frac{1}{2}\left(j^{2}{ }_{i}+k^{2}{ }_{i}\right)-\left[M^{-1} \sum_{i} \frac{1}{2}\left(j_{i}+k_{i}\right)\right]^{2}}
$$

where $M$ is the number of edges (links), $j_{i} k_{i}$ represents the degrees of nodes at the ends of ith edges.

\section{Reference}

Allen, F. and Gale,D., 2000. "Financial contagion" Journal of Political Economy 108, $1-33$.

Allen, F. and Babus, A. 2009, "Networks in Finance", in Kleindorfer, P, Wind, Y and Gunther, $\mathrm{R}$ eds, The network challenge: strategy, profit, and risk in an interlinked world, Wharton School Publishing.

Bank of Japan, 1964. Ginko Jiko Geppo (Monthly Report Bank Issue) in Bank of Japan ed., Nihon Kin'yushi Shiryo (Material on the Japanese Financial History) Showa edition, Vol. 9, Printing Bureau of the Ministry of Finance.

Battiston S, Catanzaro M. 2004 "Statistical properties of corporate board and director networks.” European Physical Journal B 38, 345.352

Barnea, A. and I. Guedj,, 2006, "But Mom, All the Kids Have One! CEO Compensation and Director Networks," University of Texas Working Paper.

Berger,A.N. 1995. "The Profit-structure relationship in banking: Test of market power and efficiency structure hypothesis," Journal of Money, Credit and Banking, 27-2 404-431 
Bertrand, M., Luttmer, E. F.P.; Mullainathan, S. 2000. "Network effects and welfare.cultures," Quarterly Journal of Economics, 115-3, 1019-1055

Bizjak, J.,Lemmon,M. and Whitby,R. 2009. "Option backdating and board interlocks Review of Financial Studies 22 -11, 4821-4847.

Boissay, F., 2006. "Credit chains and the propagation of financial distress," Working Paper Series 573, European Central Bank.

Bouke, P., 1989. "Concentration and other determinant of bank profitability in European, North America and Australia," Journal of Banking and Finance, 13-1, $65-79$

Brusco, S and Castiglionesi, F., 2007, "Liquidity coinsurance, moral hazard, and financial Contagion”, Journal of Finance, 62, 2275-302.

Conyon M.J, and Muldoon M.R. 2006. "The small world of corporate boards." Journal of Business Finance and Accounting 33-9, 1321-1343

Croci,E. and Grassi,R.(2010) "The Economic Effect of Interlocking Directorates in Italy: New Evidence Using Centrality Measures" Working Paper Università degli Studi

D’Aveni, R.A. and Kesner, I.F., 1993. "Top managerial prestige, power and tender offer response: A study of élite social. networks and target firm cooperation during takeovers,". Organization Science, 4-2, 123-51.

Davis, G. F. 1991. "Agents without principles? The spread of the poison pill through the intercorporate network". Administrative Science Quarterly, 36, 583-613.

Davis G.F, Yoo M, and Baker W.E. 2003 "The small world of the American corporate elite, 1982.2001" Strategic Organization 1-3, 301-326

Dasgupta, A. 2004. "Financial contagion through capital connections: A model of the 
origin and spread of bank panics." Journal of European Economic Association, $2-6,1049-1084$

Degryse,H. and Nguyen,G. 2004. "Interbank exposures: An empirical examination of systemic risk in the Belgian banking system," Working paper of National Bank of Belgium

Devos, E., Prevost, A. and Puthenpurackal, J., 2009, "Are Interlocked Directors Effective Monitors?" Financial Management 38, 861-887.

Fafchamps,M. and Gubert,F., 2007. "The formation of risk-sharing networks," Journal of Development Economics, 83, 326-350

Fama, E. and Jensen,M. 1983, "Separation of ownership and control," Journal of Law and Economics 26, 301-326.

Ferris, S.P., M. Jagannathan, A. Pritchard, 2003. "Too busy to mind the business?: Monitoring by directors with multiple board appointments," Journal of Finance 58, $1087-1111$

Fich, E., and Shivdasani,A. 2006, "Are Busy Boards Effective Monitors?," Journal of Finance, 61, 689-624.

Freixas, X., Parigi, B., Rochet, J.C., 2000. « Systemic risk, interbank relations and liquidity provision by the central bank," Journal of Money, Credit, and Banking 32-3, 611-638.

Furfine, C.H., 2003. "Interbank exposures: Quantifying the risk of contagion," Journal of Money, Credit, and Banking 35, 111-128

Gai,P. and Kapadia,S, 2010 "Contagion in financial networks" Bank of England Woriking Paper 383 
Gleason, K., I. Mathur, and R. Wiggins 2003. "Evidence on value creation in the financial services industries through the use of joint ventures and strategic alliances.” The Financial Review, 38, 213-235.

Goddard, J. A., Molyneux, P.M. and Wilson, J.O.S., 2001. European Banking: Efficiency, Technology and Growth, Chichester, Wiley.

Goddard, J. A., Molyneux, P.M. and Wilson, J.O.S., 2004. "The profitability of European banks: A cross-sectional and dynamic panel analysis," The Manchester School 72-3, 363-381

Goyal,S., 2007. Connections: an introduction to the economics of networks. Princeton University Press.

Hallock, K. F., 1997, "Reciprocally Interlocking Boards of Directors and Executive Compensation" The Journal of Financial and Quantitative Analysis, 32, 331-344.

Haunschild, P. R. 1993. Interorganizational imitation: The impact of interlocks on corporate acquisition activity. Administrative Science Quarterly, 38, 564-592.

Jackson, M.O., 2003. "The Stability and efficiency of economic and social networks," in Murat Sertel and Semih Koray eds., Advances in Economic Design, Springer-Verlag, Heidelberg

Jackson, M.O., 2006. The Economics of Social Network, in Richard Blundell , Whitney Newey, and Torsten Persson eds., Advances in Economics and Econometrics, Theory and Applications: Ninth World Congress of the Econometric Society, Cambridge University Press

Jackson, M.O., 2008. Social and Economic Networks, Princeton University Press, Princeton

Imakubo,K. and Soejima,Y., 2010. "The Transaction Network in Japan’s Interbank Money Markets" Monetary and Economic Studies, Bank of Japan 28, 107-150 
Imuta, T., 1980. "Nihon no kin'yu kozo no saihen to chiho ginko (Reorganization of the financial system and regional banks in Japan) in Asakura, T. eds., Ryo Taisenkan niokeru Kin'yu Kozo (Structure of the Financial System between the Two World Wars), Ochanomizu Shobo, Tokyo

Iyer, R. and Peydro,J., 2010. "Interbank Contagion at Work: Evidence from a Natural Experiment." Review of Financial Studies forthcoming

Kin'yu Kenkyukai., 1934. Waga Kuni ni okeru Giko Godo no Taisei (The Trend of Bank Mergers in Japan). Kin'yu Kenkyukai.

Leitner, Y., 2005. "Financial networks: Contagion, commitment, and private sector bailouts," Journal of Finance, 60, 2925-2953

Loderer, C., and Peyer, U. C. 2002, "Board overlap, seat accumulation, and share prices," European Financial Management, 8, 165-192.

Milakovi, M. · Alfarano,S.and Lux,T.2010 "The small core of the German corporate board network" Computational and Mathematical Organization Theory 16,201-215

McMillan, J. and Woodruff, C., 1999. "Interfirm relationships and informal credit in Vietnam," Quarterly Journal of Economics 114, 1285-1230

Ministry of Finance. (1928-1938) Ginkokyoku Nenpo (Year Book of the Bank Bureau of the Ministry of Finance) 1926-1936 issues.

Mizruchi M., 1996. "What do interlocks do?: An analysis, critique and sssessment of research on interlocking directorates," Annual Review of Sociology 22, 271-302.

Nanjo,T. and Kasuya,M., 2005. "Ginko no potoforio nikansuru ichikosatsu (Analyses of efficiency of bank portfolio in prewar Japan,) Kin'yu Kenkyu 25-1, 105-144

Newey, W.,1987. "Efficient estimation of limited dependent variable models with endogenous explanatory variables." Journal of Econometrics 36, 230-251. 
Newman, M.E.J., 2002. “ Assortative mixing in networks.” Physical Review Letters 89-20

Non, M., and Franses, P.-H., 2007, "Interlocking Boards and Firm Performance: Evidence from a New Panel Database," TI 2007-034/2 Tinbergen Institute Discussion Paper.

Okazaki,T. and Sawada,,M, 2007. "Effects of bank merger promotion policy: Evaluating Bank Law in 1927, Japan”, Financial History Review 14-1, 29-61

Okazaki, T., Sawada, M. and Yokoyama,K., 2005. "Measuring the extent and implications of director interlocking in the pre-war Japanese banking industry" Journal of Economic History 65-4, 1082-1115

Okazaki, T., Sawada, M. and Wang,K., 2007. "The fall of 'organ bank' relationships during the wave of bank failures and consolidations: Experience in pre-war Japan," Corporate Ownership and Control, 4-4, 19-38

Okazaki, T., 2007. "Micro-aspects of monetary policy: Lender of Last Resort and selection of banks in pre-war Japan," Explorations in Economic History 44, 657-679

Palmer, D. A., Jennings, P. D., \& Zhou, X., 1993. "Late adoption of the multidivisional. form by large U.S. corporations: Institutional, political, economic accounts," Administrative Science Quarterly, 38-1, 100-131.

Perry,T. and Peyer,U., 2005. "Board seat accumulation by executives: A shareholder's perspective," Journal of Finance, 60-4, 2083-2123

Pfeffer, J., and Salancik, G. R. 1978. The external control of organizations: A resource dependence perspective. NewYork: Harper \& Row.

Rao, H., and Sivakumar, K. 1999. Institutional sources of boundary-spanning structures: The establishment of investor relations departments in the Fortune 500 industrials. Organization Science, 10, 27-42. 
Robins G, AlexanderM. 2004 "Small worlds among interlocking directors: Network structure and distance in bipartite graphs.” Computational and Mathematical Organization Theory 10, 69-94

Sheldon, G. and Maurer, M., 1998. "Interbank lending and systemic risk: An empirical analysis for Switzerland," Swiss Journal of Economics and Statistics 134-4, 685-704.

Smirlock, M., 1985. "Evidence of the (non) relationship between concentration and profitability in banking," Journal of Money, Credit and Banking, Vol.17-1, 69-83

Stuart,T.E. and Yim,S., 2010 "Board interlocks and the propensity to be targeted in private equity transactions" Journal of Financial Economics 97-1, 174-189

Tokyo Koshinjo 1926. 1931. Ginko Kaisha Yakuinroku (Directory of the Banks and Firms Directors of Japan), 1926, 1931 issues, Tokyo: Tokyo Kishinjo.

Upper,C. and Worms,A., 2004. "Estimating bilateral exposures in the German interbank market: Is there a danger of contagion?," European Economic Review Volume $48-4,827-849$

Useem, M. 1982. "Classwide nationality in the politics of managers and directors of large corporations in the United States and Great Britain," Administrative Science Quarterly, 27, 199-226.

Van den Ven,W.P.M.M. and B.M.S. Van Pragg, 1981. "Demand for deductibles in private health insurance: A Probit model with sample selection," Journal of Econometrics 17, 229-252

Wasserman, S. and Faust, K., 1994. Social Network Analysis; Cambridge, Cambridge University Press

Westphal, J. D., and Zajac, E. J. 1997. Defections from the inner circle: Social exchange, reciprocity, and the diffusion of board independence in U.S. corporations. Administrative Science Quarterly, 42, 161-183. 
Wheelock, D.C. and P.W. Wilson, 2000. "Why do banks disappear?: The determinants of. US Bank failures and acquisitions," Review of Economics and Statistics 82, 127-138

White, Halbert., 1980. "A heteroscedasticity-consistent covariance matrix and direct test for heteroscedasticity," Econometrica,48, 817-838.

Yabushita, S. and A. Inoue, 1993. "The stability of the Japanese banking system: A historical perspective," Journal of the Japanese and International Economies, 7-4, 387-407

Yermack, D. 1996. "Higher market valuation of companies with a small board of directors," Journal of Financial Economics 40, 185-211 
Figure1. Average Nearest Neighbor Degree of the nodes of degree $K$

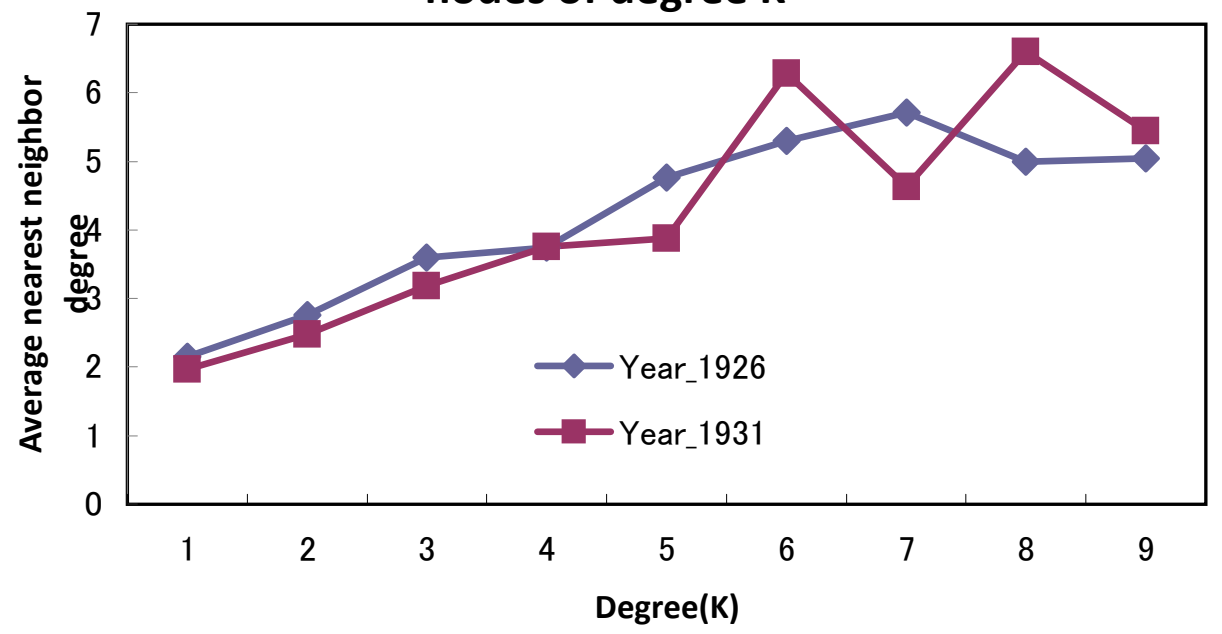

Source:Directory of Banks and Companies (the 1926 and 1931 issues) 
Figure 2 Average performance of connected banks in 1926 and 1931
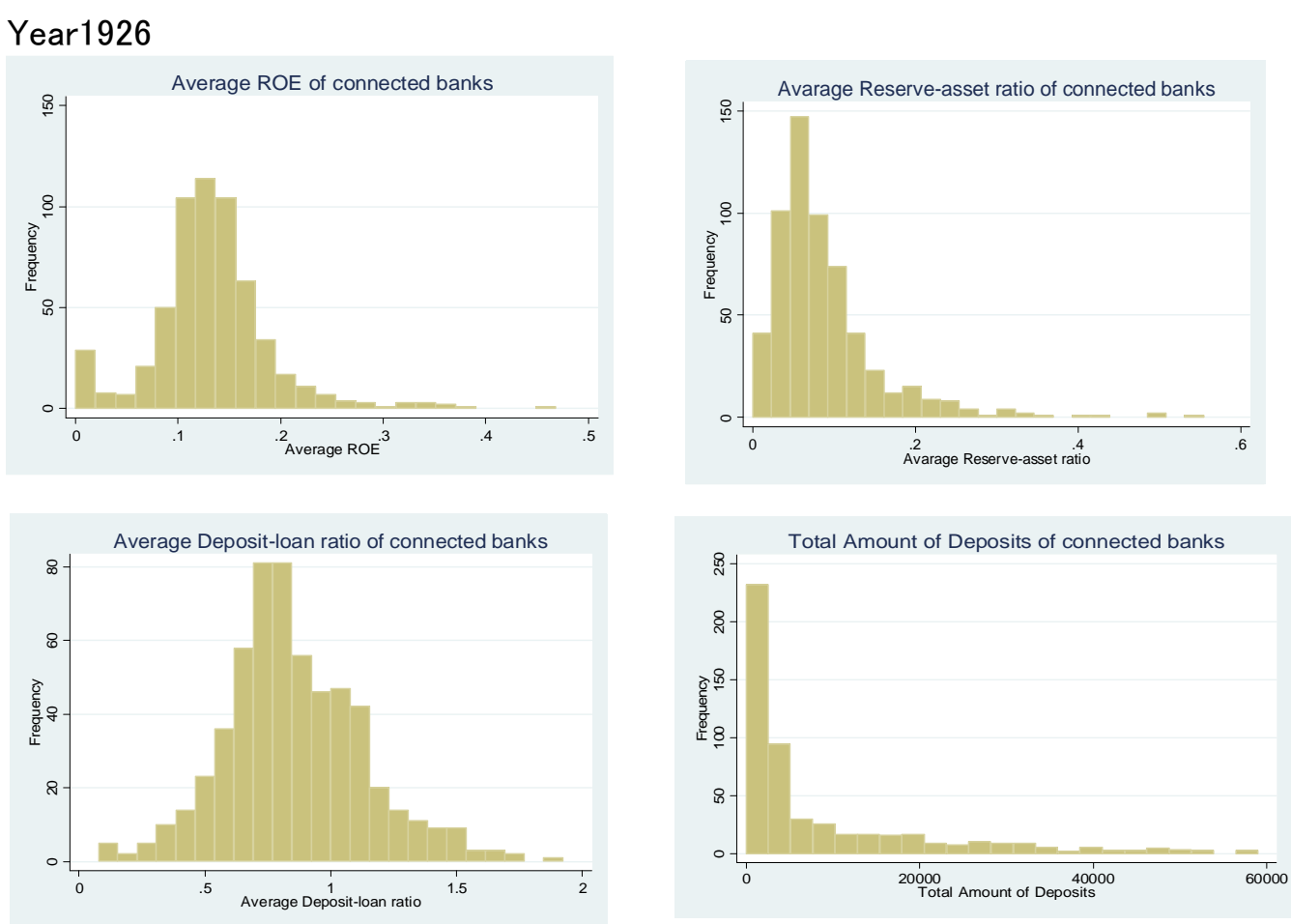

Year 1931
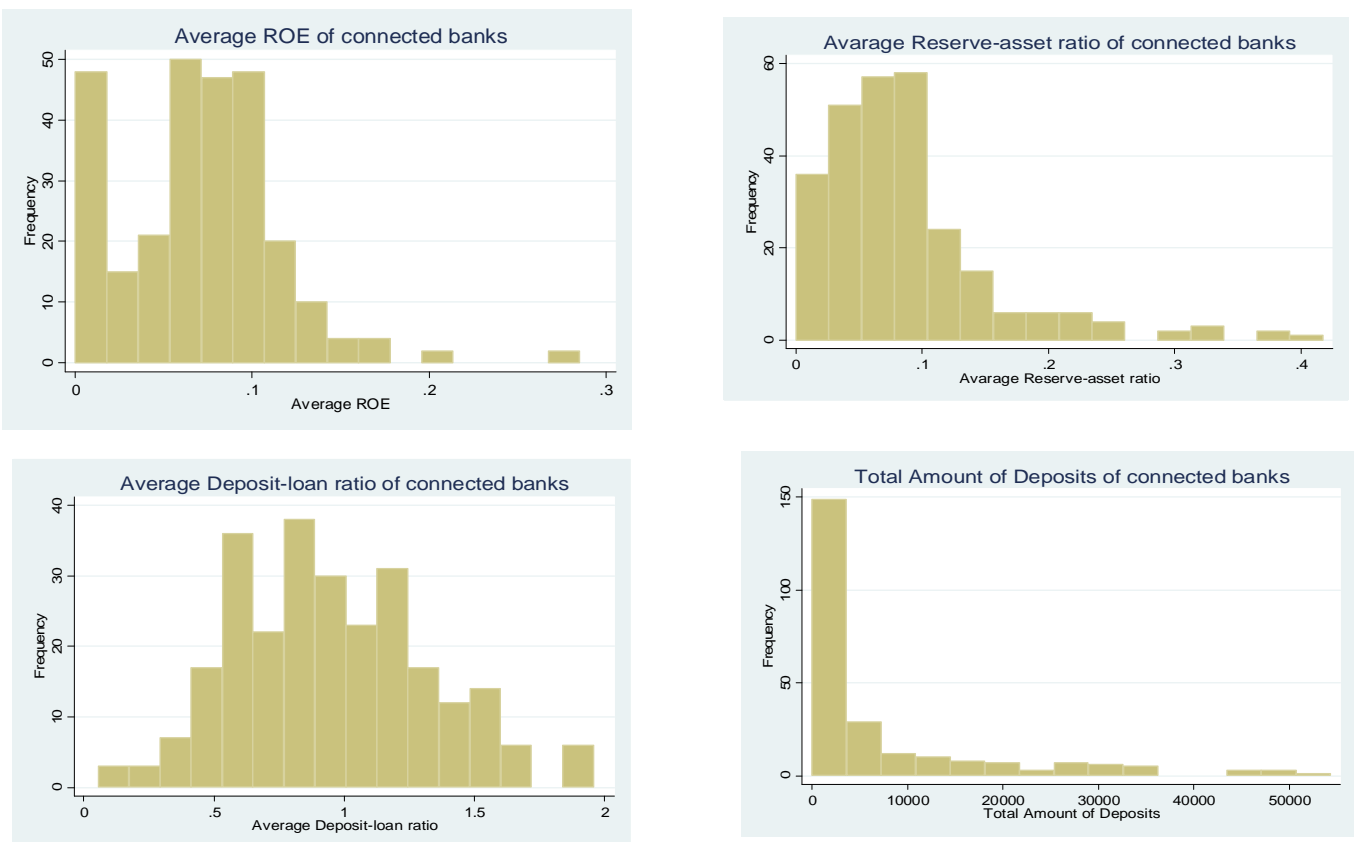

Note: These figures indicate distributions on the quality of networks with respect to the 587 banks in 1926 and 271 banks in 1931, which had at least one connection with another bank. The quality of the network of a bank (Bank $A$ for example) is measured by the average performance of the banks with which Bank $A$ was connected.

Source:Directory of Banks and Companies (the 1926 and 1931 issues) 
Table1 Distribution of the number of connections through director interlocking

Panel A: Year 1926

\begin{tabular}{rrr}
\hline \hline Number of connections & Observations & \multicolumn{1}{c}{$\%$} \\
\hline 0 & 420 & $41.71 \%$ \\
1 & 297 & $29.49 \%$ \\
2 & 146 & $14.50 \%$ \\
3 & 63 & $6.26 \%$ \\
4 & 40 & $3.97 \%$ \\
5 & 16 & $1.59 \%$ \\
6 & 10 & $0.99 \%$ \\
7 & 4 & $0.40 \%$ \\
8 & 1 & $0.10 \%$ \\
9 & 5 & $0.50 \%$ \\
10 & 2 & $0.20 \%$ \\
11 & 2 & $0.20 \%$ \\
13 & 1 & $0.10 \%$ \\
\hline Total & 1007 & $100 \%$ \\
Number of connections $\geqq 1$ & 587 & $58.3 \%$ \\
\hline \hline
\end{tabular}

Panel B: Year 1931

\begin{tabular}{rrr}
\hline Panel B: Year 1931 & & \\
\hline Number of connections & Observations & $\%$ \\
\hline 0 & 326 & $54.61 \%$ \\
1 & 162 & $16.09 \%$ \\
2 & 63 & $6.26 \%$ \\
3 & 16 & $1.59 \%$ \\
4 & 11 & $1.09 \%$ \\
5 & 5 & $0.50 \%$ \\
6 & 3 & $0.30 \%$ \\
7 & 5 & $0.50 \%$ \\
8 & 4 & $0.40 \%$ \\
9 & 2 & $0.20 \%$ \\
\hline Notal & 597 & $100 \%$ \\
Number of connections $\geqq 1$ & 271 & $45.4 \%$ \\
\hline \hline
\end{tabular}


Table2 Structure of interbank networks

Panel A: Distribution of the number of nodes (banks) in each component

\begin{tabular}{rrr}
$\begin{array}{c}\text { Year } 1926 \\
\text { Number of } \\
\text { nodes }\end{array}$ & $\begin{array}{c}\text { Number of } \\
\text { Components }\end{array}$ & $\begin{array}{c}\text { Number of } \\
\text { Observations }\end{array}$ \\
2 & 84 & 168 \\
3 & 21 & 63 \\
4 & 11 & 44 \\
5 & 4 & 20 \\
6 & 2 & 12 \\
7 & 3 & 21 \\
10 & 1 & 10 \\
12 & 2 & 24 \\
16 & 1 & 16 \\
17 & 1 & 17 \\
18 & 1 & 18 \\
19 & 1 & 19 \\
20 & 1 & 20 \\
28 & 1 & 28 \\
29 & 2 & 58 \\
49 & 1 & 49 \\
\hline Total & 137 & 587 \\
\hline \hline
\end{tabular}

\begin{tabular}{rrr}
\multicolumn{1}{l}{$\begin{array}{c}\text { Year 1931 } \\
\text { nomber of }\end{array}$} & $\begin{array}{c}\text { Number of } \\
\text { Components }\end{array}$ & $\begin{array}{c}\text { Number of } \\
\text { Observations }\end{array}$ \\
\hline 2 & 45 & 90 \\
3 & 16 & 48 \\
4 & 3 & 12 \\
5 & 2 & 10 \\
6 & 5 & 30 \\
9 & 1 & 9 \\
11 & 1 & 11 \\
15 & 1 & 15 \\
46 & 1 & 46 \\
\hline Total & 75 & 271 \\
\hline \hline
\end{tabular}

Panel B Network Measures

\begin{tabular}{lcccc}
\hline \hline & \multicolumn{2}{c}{ Year 1926 (obs=587) } & \multicolumn{2}{c}{ Year 1931(obs=271) } \\
\cline { 2 - 5 } Types & Mean (Value) & Std. Dev. & Mean (Value) & Std. Dev. \\
\hline Degree (Number of connections) & 2.068 & 1.659 & 1.875 & 1.584 \\
Core-degree & 1.566 & 0.877 & 1.458 & 0.953 \\
Clustering Coefficient & 0.241 & 0.383 & 0.190 & 0.360 \\
Assortativity coefficient & 0.364 & - & 0.554 & - \\
Average Nearest Neighbor Degree & 2.768 & 2.025 & 2.455 & 1.790 \\
\hline
\end{tabular}

Panel C Regional characteristics of interbank network.

\begin{tabular}{lrr}
\hline \hline Types & Year 1926 & Year 1931 \\
\hline Intra-regional network & 402 & 187 \\
Inter-regional network & 185 & 84 \\
\hline Total & 587 & 271 \\
\hline \hline
\end{tabular}


Table3 Basic Statistics

Panel A Banks with networks

\begin{tabular}{lrrrrrr}
\hline Variable & \multicolumn{1}{c}{ Obs } & \multicolumn{1}{c}{ Mean } & Std. Dev. & \multicolumn{1}{c}{ Min } & Max & T-statistics \\
\hline Capitals/Deposits & 858 & 0.891 & 3.759 & 0.018 & 101.377 & -0.76 \\
Reserves/Total assets & 858 & 0.090 & 0.085 & 0.000 & 0.767 & 2.65 \\
ROE & 858 & 0.114 & 0.077 & 0.000 & 0.732 & 3.57 \\
Securities/Loans & 858 & 0.198 & 0.310 & 0.000 & 3.791 & -0.85 \\
Deposits/Loans & 858 & 0.920 & 0.619 & 0.003 & 10.382 & 0.23 \\
Amount of Total deposits (thousand yen & 858 & 15714.90 & 65426.28 & 1.95 & 663882.5 & 4.51 \\
Amount of Total assets (thousand yen) & 858 & 19358.65 & 78652.53 & 56.71 & 775622.4 & 4.51 \\
\hline
\end{tabular}

Panel B Banks without networks

\begin{tabular}{lrrrrr}
\hline Variable & Obs & \multicolumn{1}{c}{ Mean } & Std. Dev. & \multicolumn{1}{c}{ Min } & \multicolumn{1}{c}{ Max } \\
\hline Capitals/Deposits & 746 & 1.093 & 7.275 & 0.052 & 195.097 \\
Reserves/Total assets & 746 & 0.093 & 0.083 & 0.000 & 0.641 \\
ROE & 746 & 0.100 & 0.078 & 0.000 & 0.698 \\
Securities/Loans & 746 & 0.214 & 0.438 & 0.000 & 6.447 \\
Deposits/Loans & 746 & 1.298 & 9.292 & 0.008 & 253.108 \\
Amount of Total deposits (thousand yen & 746 & 4544.96 & 18561.57 & 1.59 & 425911.3 \\
Amount of Total assets (thousand yen) & 746 & 5927.27 & 22054.92 & 176.27 & 505237.1 \\
\hline
\end{tabular}

$\mathrm{T}$-statistic tests the hypothesis that there is no difference between banks within networks and

ones outside networks 
Table4 Interbank networks and survivability

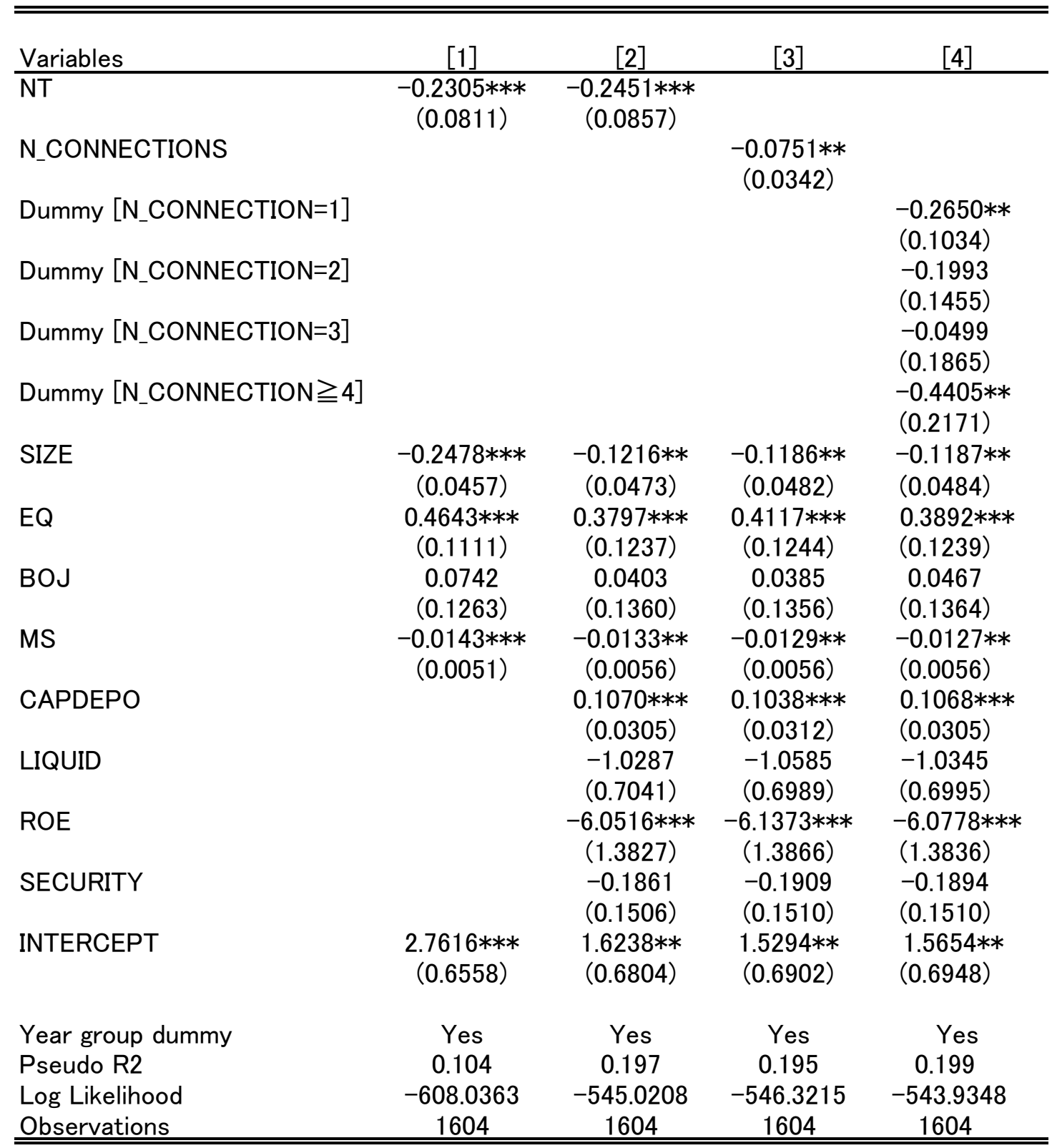

Notes:

Significance at $1 \%, 5 \%$ and $10 \%$ level are denoted by "***" " $* *$ " and "*".

The figures in parentheses are standard errors. 
Table5 Interbank networks and survivability, controlling for the endogeneity of interbank network

\begin{tabular}{|c|c|c|c|c|c|c|}
\hline \multirow{2}{*}{$\begin{array}{l}\text { Methodology } \\
\text { Dependent variable }\end{array}$} & \multicolumn{2}{|c|}{$\begin{array}{c}\text { Model 1 } \\
\text { Bivariate Probit }\end{array}$} & \multicolumn{2}{|c|}{$\begin{array}{c}\text { Model } 2 \\
\text { Bivariate Probit }\end{array}$} & \multicolumn{2}{|c|}{$\begin{array}{c}\text { Model } 3 \\
\text { IV Probit }\end{array}$} \\
\hline & $\operatorname{Pr}($ Fail=1) & NT & $\operatorname{Pr}($ Fail=1) & NT & $\operatorname{Pr}($ Fail=1) & N_CONNECTION \\
\hline \multicolumn{7}{|l|}{$\begin{array}{l}\text { Explanatory variables } \\
\text { (Endogenous Variables) }\end{array}$} \\
\hline NT & $\begin{array}{l}-1.4105 * * * \\
\quad(0.1740)\end{array}$ & & $\begin{array}{l}-1.4259 * * * \\
(0.1499)\end{array}$ & & & \\
\hline N_CONNECTION & & & & & $\begin{array}{c}-0.8206 * * * \\
(0.2279)\end{array}$ & \\
\hline \multicolumn{7}{|l|}{ (Instrument Variables) } \\
\hline N_BANK & & $\begin{array}{l}0.0027 * * \\
(0.0013)\end{array}$ & & $\begin{array}{c}0.0028 * * \\
(0.0013)\end{array}$ & & $\begin{array}{r}0.0030 * \\
(0.0016)\end{array}$ \\
\hline N_DIRECTOR & & $\begin{array}{l}0.0508 * * * \\
(0.0102)\end{array}$ & & $\begin{array}{l}0.0539 * * * \\
(0.0103)\end{array}$ & & $\begin{array}{l}0.0806 * * * \\
(0.0127)\end{array}$ \\
\hline \multicolumn{7}{|c|}{ (Other Control Variables) } \\
\hline SIZE & $\begin{array}{c}-0.1460 * * * \\
(0.0429)\end{array}$ & $\begin{array}{c}0.0985 * * * \\
(0.0316)\end{array}$ & $\begin{array}{l}-0.0389 \\
(0.0410)\end{array}$ & $\begin{array}{l}0.0939 * * * \\
(0.0326)\end{array}$ & $\begin{array}{c}0.0860 \\
(0.0813)\end{array}$ & $\begin{array}{l}0.2087 * * * \\
(0.0376)\end{array}$ \\
\hline$E Q$ & $\begin{array}{c}0.2376 * * \\
(0.1152)\end{array}$ & $\begin{array}{l}-0.2180 * * \\
(0.1005)\end{array}$ & $\begin{array}{c}0.1866 \\
(0.1146)\end{array}$ & $\begin{array}{c}-0.1907 * \\
(0.1015)\end{array}$ & $\begin{array}{l}0.5754 * * * \\
(0.1599)\end{array}$ & $\begin{array}{l}0.3414 * * * \\
(0.1166)\end{array}$ \\
\hline BOJ & $\begin{array}{c}0.1130 \\
(0.1125)\end{array}$ & $\begin{array}{l}0.1765 * \\
(0.0965)\end{array}$ & $\begin{array}{c}0.0816 \\
(0.1180)\end{array}$ & $\begin{array}{l}0.1848 * \\
(0.0977)\end{array}$ & $\begin{array}{l}0.0836 \\
(0.1607)\end{array}$ & $\begin{array}{l}0.1208 \\
(0.1132)\end{array}$ \\
\hline MS & $\begin{array}{l}-0.0136 * * * \\
(0.0042)\end{array}$ & $\begin{array}{c}0.0004 \\
(0.0039)\end{array}$ & $\begin{array}{l}-0.0122 * * * \\
(0.0045)\end{array}$ & $\begin{array}{c}0.0003 \\
(0.0039)\end{array}$ & $\begin{array}{l}-0.0129 * * \\
(0.0057)\end{array}$ & $\begin{array}{c}0.0048 \\
(0.0045)\end{array}$ \\
\hline CAPDEPO & & & $\begin{array}{c}0.0854 * * * \\
(0.0250)\end{array}$ & $\begin{array}{l}0.0000 \\
(0.0056)\end{array}$ & $\begin{array}{c}0.1074 * * * \\
(0.0316)\end{array}$ & $\begin{array}{c}0.0001 \\
(0.0066)\end{array}$ \\
\hline LIQUID & & & $\begin{array}{c}-1.0450 * * \\
(0.4528)\end{array}$ & $\begin{array}{l}-0.2109 \\
(0.3905)\end{array}$ & $\begin{array}{c}-1.4948 * * \\
(0.6289)\end{array}$ & $\begin{array}{l}-0.4493 \\
(0.4506)\end{array}$ \\
\hline ROE & & & $\begin{array}{c}-4.6253 * * * \\
(0.7453)\end{array}$ & $\begin{array}{c}0.5201 \\
(0.4716)\end{array}$ & $\begin{array}{c}-6.0070 * * * \\
(0.8541)\end{array}$ & $\begin{array}{c}0.3064 \\
(0.5431)\end{array}$ \\
\hline SECURITY & & & $\begin{array}{c}-0.2070 * * \\
(0.1033)\end{array}$ & $\begin{array}{l}-0.0613 \\
(0.0908)\end{array}$ & $\begin{array}{c}-0.3830 * * \\
(0.1540)\end{array}$ & $\begin{array}{l}-0.1843 * \\
(0.1046)\end{array}$ \\
\hline INTERCEPT & $\begin{array}{c}2.2007 * * * \\
(0.5550)\end{array}$ & $\begin{array}{c}-1.8294 * * * \\
(0.4661)\end{array}$ & $\begin{array}{l}1.1838 * * \\
(0.5819)\end{array}$ & $\begin{array}{c}-1.8371 * * * \\
(0.4744)\end{array}$ & $\begin{array}{l}-0.5970 \\
(1.0027)\end{array}$ & $\begin{array}{l}-2.9108 * * * \\
(0.5396)\end{array}$ \\
\hline $\begin{array}{l}\text { Year group dummy } \\
\text { Log likelihood } \\
\text { Observations }\end{array}$ & $\begin{array}{r} \\
-165 \\
1 \\
\end{array}$ & 3589 & $\begin{array}{r}Y \\
-159 \\
1 \\
\end{array}$ & 524 & & $\begin{array}{l}\text { Yes } \\
397.7127 \\
1604\end{array}$ \\
\hline
\end{tabular}

Observations

standard errors. 
Table6 Network structure and survivability

\begin{tabular}{|c|c|c|c|c|c|}
\hline Variables & [1] & [2] & [3] & [4] & [5] \\
\hline NT & $\begin{array}{l}-0.1776 \\
(0.1361)\end{array}$ & $\begin{array}{l}-0.0417 \\
(0.2353)\end{array}$ & $\begin{array}{l}-0.0854 \\
(0.1205)\end{array}$ & $\begin{array}{l}-0.2092 * * \\
(0.1013)\end{array}$ & $\begin{array}{l}-0.2598 * * * \\
(0.0960)\end{array}$ \\
\hline NT*(Core Degree) & $\begin{array}{l}-0.0463 \\
(0.0731)\end{array}$ & & & & \\
\hline $\begin{array}{l}\text { NT } * \text { (Clustering } \\
\text { Coefficient }+1)\end{array}$ & & $\begin{array}{l}-0.1687 \\
(0.1836)\end{array}$ & & & \\
\hline $\begin{array}{l}\text { NT*(Average Nearest } \\
\text { Neighbor Degree) }\end{array}$ & & & $\begin{array}{c}-0.0642 * \\
(0.0349)\end{array}$ & & \\
\hline NT*(Size of component) & & & & $\begin{array}{l}-0.0031 \\
(0.0049)\end{array}$ & \\
\hline $\begin{array}{l}\text { NT*(Inter-regional network } \\
\text { Dummy) }\end{array}$ & & & & & $\begin{array}{c}0.0523 \\
(0.1496)\end{array}$ \\
\hline SIZE & $\begin{array}{c}-0.1193 * * \\
(0.0477)\end{array}$ & $\begin{array}{c}-0.1204 * * \\
(0.0473)\end{array}$ & $\begin{array}{c}-0.1137 * * \\
(0.0476)\end{array}$ & $\begin{array}{l}-0.1175 * * \\
(0.0481)\end{array}$ & $\begin{array}{l}-0.1235 * * * \\
(0.0479)\end{array}$ \\
\hline$E Q$ & $\begin{array}{c}0.3874 * * * \\
(0.1249)\end{array}$ & $\begin{array}{l}0.3855 * * * \\
(0.1243)\end{array}$ & $\begin{array}{l}0.4100 * * * \\
(0.1266)\end{array}$ & $\begin{array}{l}0.3983 * * * \\
(0.1291)\end{array}$ & $\begin{array}{l}0.3740 * * * \\
(0.1264)\end{array}$ \\
\hline BOJ & $\begin{array}{c}0.0409 \\
(0.1360)\end{array}$ & $\begin{array}{c}0.0380 \\
(0.1363)\end{array}$ & $\begin{array}{c}0.0299 \\
(0.1356)\end{array}$ & $\begin{array}{l}0.0398 \\
(0.1361)\end{array}$ & $\begin{array}{c}0.0384 \\
(0.1368)\end{array}$ \\
\hline MS & $\begin{array}{l}-0.0132 * * \\
(0.0056)\end{array}$ & $\begin{array}{l}-0.0133 * * \\
(0.0056)\end{array}$ & $\begin{array}{l}-0.0129 * * \\
(0.0056)\end{array}$ & $\begin{array}{l}-0.0131 * * \\
(0.0056)\end{array}$ & $\begin{array}{l}-0.0134 * * \\
(0.0056)\end{array}$ \\
\hline CAPDEPO & $\begin{array}{l}0.1061 * * * \\
(0.0305)\end{array}$ & $\begin{array}{l}0.1057 * * * \\
(0.0305)\end{array}$ & $\begin{array}{l}0.1110 * * * \\
(0.0298)\end{array}$ & $\begin{array}{l}0.1067 * * * \\
(0.0304)\end{array}$ & $\begin{array}{l}0.1070 * * * \\
(0.0305)\end{array}$ \\
\hline LIQUID & $\begin{array}{l}-1.0378 \\
(0.7041)\end{array}$ & $\begin{array}{l}-1.0376 \\
(0.7074)\end{array}$ & $\begin{array}{l}-1.0220 \\
(0.7064)\end{array}$ & $\begin{array}{l}-1.0146 \\
(0.7067)\end{array}$ & $\begin{array}{l}-1.0226 \\
(0.7024)\end{array}$ \\
\hline ROE & $\begin{array}{l}-6.0628 * * * \\
(1.3799)\end{array}$ & $\begin{array}{l}-6.0592 * * * \\
(1.3790)\end{array}$ & $\begin{array}{l}-6.0655 * * * \\
(1.3818)\end{array}$ & $\begin{array}{l}-6.0503 * * * \\
(1.3836)\end{array}$ & $\begin{array}{c}-6.0496 * * * \\
(1.3809)\end{array}$ \\
\hline SECURITY & $\begin{array}{c}-0.1882 \\
(0.1508)\end{array}$ & $\begin{array}{l}-0.1864 \\
(0.1502)\end{array}$ & $\begin{array}{l}-0.1889 \\
(0.1489)\end{array}$ & $\begin{array}{l}-0.1864 \\
(0.1496)\end{array}$ & $\begin{array}{l}-0.1840 \\
(0.1507)\end{array}$ \\
\hline INTERCEPT & $\begin{array}{c}1.5930 * * \\
(0.6865)\end{array}$ & $\begin{array}{c}1.6103 * * \\
(0.6789)\end{array}$ & $\begin{array}{c}1.4972 * * \\
(0.6846)\end{array}$ & $\begin{array}{l}1.5581 * * \\
(0.6936)\end{array}$ & $\begin{array}{l}1.6541 * * \\
(0.6918)\end{array}$ \\
\hline Year group dummy & Yes & Yes & Yes & Yes & Yes \\
\hline Pseudo R2 & 0.197 & 0.198 & 0.199 & 0.197 & 0.197 \\
\hline Log Likelihood & -544.8214 & -544.5431 & -543.4980 & -544.7944 & -544.9518 \\
\hline Observations & 1604 & 1604 & 1604 & 1604 & 1604 \\
\hline
\end{tabular}

Notes:

Significance at $1 \%, 5 \%$ and $10 \%$ level are denoted by " $* * *$ " " $* *$ " and " $*$ ".

The figures in parentheses are standard errors. 
Table7 Network quality and survivability

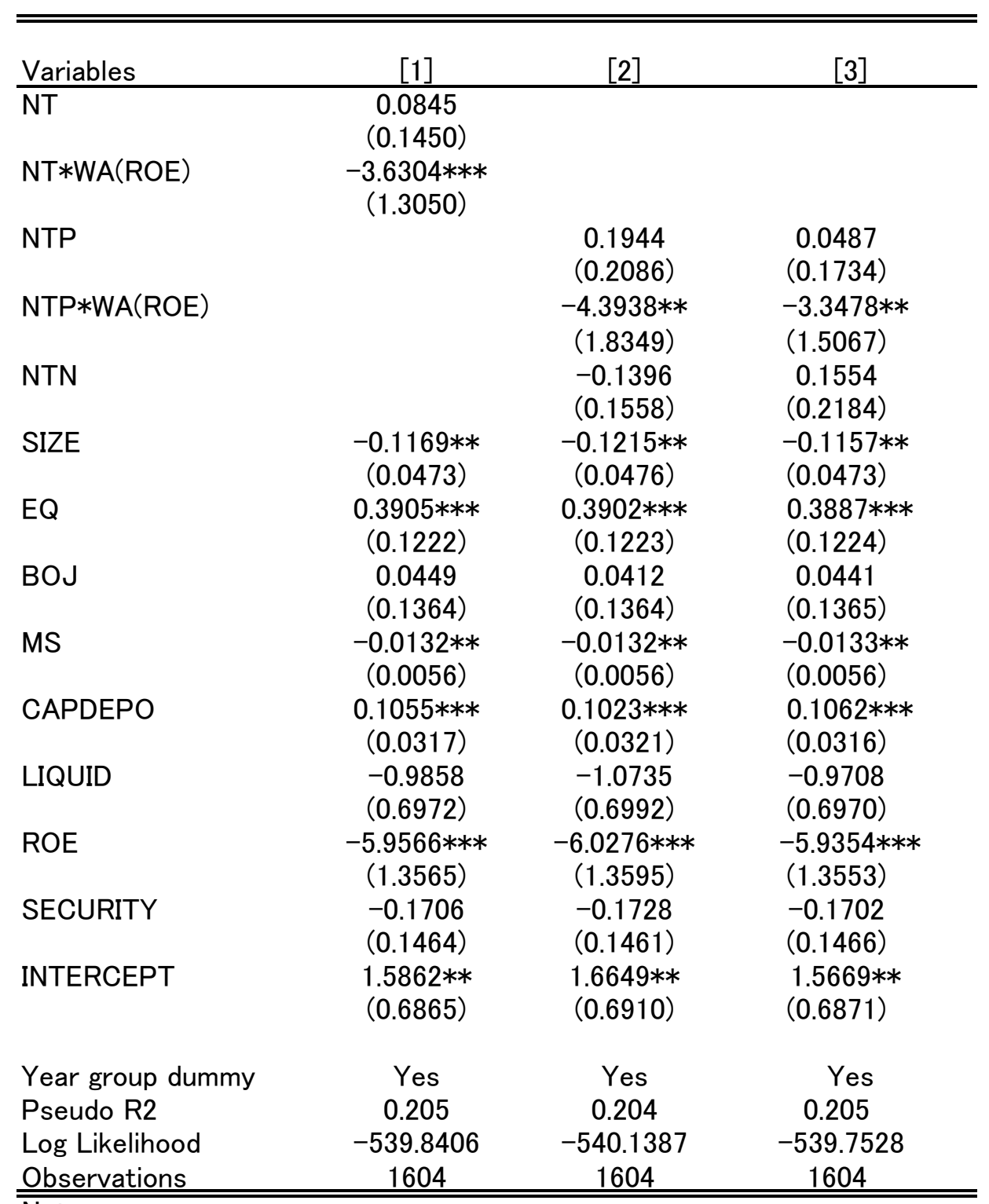

Notes:

Significance at $1 \%, 5 \%$ and $10 \%$ level are denoted by " $* * *$ " " $* *$ " and " $*$ ".

The figures in parentheses are standard errors. 
Table8 Interbank networks and contagious withdrawal of deposits

\begin{tabular}{|c|c|c|c|c|c|c|c|c|}
\hline & Dependent vo & able: Depos & Growth Rate & & & & & \\
\hline & $\begin{array}{c}\text { OLS } \\
{[1]} \\
\end{array}$ & $\begin{array}{c}\text { OLS } \\
{[2]} \\
\end{array}$ & $\begin{array}{c}\text { OLS } \\
{[3]} \\
\end{array}$ & $\begin{array}{l}\text { OLS } \\
{[4]}\end{array}$ & $\begin{array}{l}\text { IV } \\
{[5]}\end{array}$ & $\begin{array}{l}\text { IV } \\
{[6]}\end{array}$ & $\begin{array}{l}\text { IV } \\
\text { [7] }\end{array}$ & $\begin{array}{l}\text { IV } \\
{[8]}\end{array}$ \\
\hline NT & $\begin{array}{l}0.00561 \\
(0.0146)\end{array}$ & $\begin{array}{c}0.0133 \\
(0.0143)\end{array}$ & & & $\begin{array}{c}0.191 \\
(0.141)\end{array}$ & $\begin{array}{c}0.207 \\
(0.133)\end{array}$ & & \\
\hline NT*WA(GDEPO) & $\begin{array}{c}0.0112 \\
(0.0105)\end{array}$ & $\begin{array}{c}0.0144 \\
(0.0109)\end{array}$ & & & $\begin{array}{c}0.138 \\
(0.698)\end{array}$ & $\begin{array}{l}-0.260 \\
(0.592)\end{array}$ & & \\
\hline NTN & & & $\begin{array}{c}-0.00332 \\
(0.0175)\end{array}$ & $\begin{array}{l}0.00269 \\
(0.0171)\end{array}$ & & & $\begin{array}{l}0.0792 \\
(0.446)\end{array}$ & $\begin{array}{c}0.334 \\
(0.267)\end{array}$ \\
\hline NTP & & & $\begin{array}{c}0.0191 \\
(0.0165)\end{array}$ & $\begin{array}{c}0.0293 * \\
(0.0164)\end{array}$ & & & $\begin{array}{c}0.247 \\
(0.398)\end{array}$ & $\begin{array}{c}0.143 \\
(0.221)\end{array}$ \\
\hline$M \& A$ & $\begin{array}{c}0.0376 \\
(0.0232)\end{array}$ & $\begin{array}{c}0.0511 * * \\
(0.0230)\end{array}$ & $\begin{array}{c}0.0374 \\
(0.0232)\end{array}$ & $\begin{array}{l}0.0510 * * \\
(0.0230)\end{array}$ & $\begin{array}{c}0.0562 \\
(0.0650)\end{array}$ & $\begin{array}{c}0.0414 \\
(0.0543)\end{array}$ & $\begin{array}{c}0.0487 \\
(0.0331)\end{array}$ & $\begin{array}{c}0.0548 \\
(0.0365)\end{array}$ \\
\hline SIZE & $\begin{array}{l}-0.0122 * \\
(0.00722)\end{array}$ & $\begin{array}{c}-0.0147 * * \\
(0.00715)\end{array}$ & $\begin{array}{c}-0.0121 * \\
(0.00722)\end{array}$ & $\begin{array}{l}-0.0146 * * \\
(0.00714)\end{array}$ & $\begin{array}{l}-0.0289 \\
(0.0278)\end{array}$ & $\begin{array}{l}-0.0217 \\
(0.0203)\end{array}$ & $\begin{array}{c}-0.0232 * * \\
(0.0102)\end{array}$ & $\begin{array}{l}-0.0286 * * \\
(0.0123)\end{array}$ \\
\hline ROE & $\begin{array}{c}0.284 * * \\
(0.128)\end{array}$ & $\begin{array}{c}0.321 * * \\
(0.125)\end{array}$ & $\begin{array}{c}0.286 * * \\
(0.128)\end{array}$ & $\begin{array}{l}0.324 * * \\
(0.126)\end{array}$ & $\begin{array}{c}0.225 \\
(0.161)\end{array}$ & $\begin{array}{c}0.301 \\
(0.187)\end{array}$ & $\begin{array}{c}0.259 \\
(0.176)\end{array}$ & $\begin{array}{c}0.232 \\
(0.157)\end{array}$ \\
\hline CAPDEPO & $\begin{array}{c}0.00111 * * * * \\
(0.000420)\end{array}$ & $\begin{array}{c}0.000524 \\
(0.000326)\end{array}$ & $\begin{array}{c}0.00112 * * * \\
(0.000419)\end{array}$ & $\begin{array}{r}0.000543 * \\
(0.000324)\end{array}$ & $\begin{array}{c}0.00108 \\
(0.000673)\end{array}$ & $\begin{array}{c}0.000896 * * \\
(0.000437)\end{array}$ & $\begin{array}{c}0.00119 * * * \\
(0.000454)\end{array}$ & $\begin{array}{c}0.000794 \\
(0.000508)\end{array}$ \\
\hline LIQUID & $\begin{array}{l}-0.131 \\
(0.116)\end{array}$ & $\begin{array}{l}-0.168 \\
(0.118)\end{array}$ & $\begin{array}{l}-0.134 \\
(0.116)\end{array}$ & $\begin{array}{l}-0.173 \\
(0.118)\end{array}$ & $\begin{array}{c}-0.0861 \\
(0.145)\end{array}$ & $\begin{array}{l}-0.114 \\
(0.165)\end{array}$ & $\begin{array}{l}-0.123 \\
(0.179)\end{array}$ & $\begin{array}{c}-0.0313 \\
(0.174)\end{array}$ \\
\hline SECURITY & $\begin{array}{c}0.0758 * * * \\
(0.0240)\end{array}$ & $\begin{array}{c}0.0651 * * * \\
(0.0249)\end{array}$ & $\begin{array}{c}0.0756 * * * \\
(0.0241)\end{array}$ & $\begin{array}{l}0.0649 * * * \\
(0.0250)\end{array}$ & $\begin{array}{c}0.0633 * * \\
(0.0285)\end{array}$ & $\begin{array}{c}0.0517 \\
(0.0457)\end{array}$ & $\begin{array}{c}0.0646 * * \\
(0.0285)\end{array}$ & $\begin{array}{c}0.0530 \\
(0.0397)\end{array}$ \\
\hline INTERCEPT & $\begin{array}{c}0.113 \\
(0.107)\end{array}$ & $\begin{array}{c}0.111 \\
(0.106)\end{array}$ & $\begin{array}{c}0.110 \\
(0.107)\end{array}$ & $\begin{array}{c}0.108 \\
(0.106)\end{array}$ & $\begin{array}{c}0.247 \\
(0.345)\end{array}$ & $\begin{array}{c}0.113 \\
(0.248)\end{array}$ & $\begin{array}{c}0.186 \\
(0.121)\end{array}$ & $\begin{array}{c}0.186 \\
(0.136)\end{array}$ \\
\hline Area dummies & Yes & No & Yes & No & Yes & No & Yes & No \\
\hline R2 & 0.058 & 0.029 & 0.059 & 0.030 & - & - & - & - \\
\hline Observations & 816 & 816 & 816 & 816 & 816 & 816 & 816 & 816 \\
\hline
\end{tabular}

\section{Notes:}

Significance at $1 \%, 5 \%$ and $10 \%$ level are denoted by " $* * *$ " " $* *$ " and "*".

The figures in parentheses are standard errors. 
Table 9 Comparison of the ratio of banks with connections among merged banks to that among banks not merged during the period 1927-29

\begin{tabular}{lcc}
\hline \hline & Banks not merged & Merged banks \\
\hline Within networks & 265 & 155 \\
Outside networks & 292 & 295 \\
$\%$ of banks outside networks & $52.4 \%$ & $65.6 \%$ \\
\hline
\end{tabular}


Table10 Interbank networks and bank consolidations during the period 1927-29

Panel A: Form of consolidation

\begin{tabular}{lccc}
\hline \hline Types & Number of events & Number of Intra-network & $\%$ \\
\hline Absorptions & 94 & 27 & $28.7 \%$ \\
Combination into a new bank & 25 & 14 & $56.0 \%$ \\
Acquisitions & 54 & 14 & $25.9 \%$ \\
\hline Total & 173 & 55 & $31.8 \%$ \\
\hline
\end{tabular}

Panel B: Number of participants

\begin{tabular}{lccc}
\hline \hline Types & Number of events & Number of Intra-network & $\%$ \\
\hline One-to-one & 154 & 42 & $27.3 \%$ \\
More than two & 19 & 13 & $68.4 \%$ \\
\hline Total & 173 & 55 & $31.8 \%$ \\
\hline
\end{tabular}

Panel C: Regional characteristics

\begin{tabular}{lccc}
\hline Types & Number of events & Number of Intra-network & $\%$ \\
\hline Intra-regional & 146 & 49 & $33.6 \%$ \\
Inter-regional & 27 & 6 & $22.2 \%$ \\
\hline Total & 173 & 55 & $31.8 \%$ \\
\hline
\end{tabular}

Panel D: Policy-promoted versus Strategic consolidations

\begin{tabular}{lccc}
\hline \hline Types & Number of events & Number of Intra-network & $\%$ \\
\hline Policy-promoted & 79 & 23 & $29.1 \%$ \\
Strategic consolidation & 94 & 32 & $34.0 \%$ \\
\hline Total & 173 & 55 & $31.8 \%$ \\
\hline
\end{tabular}


Table11 Interbank networks and choice of partner banks

Panel A: Type of Consolidations

$$
\begin{array}{lll}
\text { All consolidation Absorptions } & \text { Acquisitions } & \begin{array}{l}
\text { Combination } \\
\text { into a new bank }
\end{array}
\end{array}
$$

\begin{tabular}{lcccc} 
Variables & {$[1]$} & {$[2]$} & {$[3]$} & {$[4]$} \\
\hline NT & $2.8113 * * *$ & $1.9442 * * *$ & $2.0950 * * *$ & $2.6166 * * *$ \\
& $(0.2466)$ & $(0.2724)$ & $(0.3582)$ & $(0.3054)$ \\
PREF & $5.0681 * * *$ & $5.0545 * * *$ & $4.2533 * * *$ & $6.9611 * * *$ \\
& $(0.2116)$ & $(0.2919)$ & $(0.3484)$ & $(1.0466)$ \\
INTERCEPT & $-7.4196 * * *$ & $-8.0405 * * *$ & $-8.2492 * * *$ & $-10.8191 * * *$ \\
& $(0.1817)$ & $(0.2495)$ & $(0.2772)$ & $(0.9982)$ \\
& & & & \\
Pseudo & 0.472 & 0.398 & 0.299 & 0.498 \\
Observations & 51040 & 51040 & 51040 & 51040 \\
\hline \hline
\end{tabular}

Panel B: Regional characteristics

\begin{tabular}{lcc}
\hline \hline & Intra-regional & Inter-regional \\
\cline { 2 - 3 } & {$[1]$} & {$[2]$} \\
\hline NT & $5.5278 * * *$ & $4.4878 * * *$ \\
INTERCEPT & $(0.1878)$ & $(0.4640)$ \\
& $-5.9221 * * *$ & $-7.6589 * * *$ \\
& $(0.0859)$ & $(0.2041)$ \\
Pseudo & 0.190 & 0.080 \\
Observations & 51040 & 51040 \\
\hline \hline
\end{tabular}

Panel C: Policy-promoted versus Strategic consolidations

\begin{tabular}{lcc}
\hline \hline & Policy-promoted & Strategic \\
Variables & {$[1]$} & {$[2]$} \\
\hline NT & $1.9748 * * *$ & $2.5854 * * *$ \\
& $(0.2739)$ & $(0.2513)$ \\
PREF & $5.4003 * * *$ & $4.6316 * * *$ \\
& $(0.3429)$ & $(0.2665)$ \\
INTERCEPT & $-8.4155 * * *$ & $-7.8226 * * *$ \\
& $(0.3010)$ & $(0.2233)$ \\
& & \\
Pseudo & 0.425 & 0.402 \\
Observations & 51040 & 51040 \\
\hline \hline
\end{tabular}

Significance at $1 \%, 5 \%$ and $10 \%$ level are denoted by " $* * *$ " " $* *$ " and " $*$ ".

The figures in parentheses are standard errors. 
Table12 Number of samples by event year

\begin{tabular}{cccr}
\hline \hline Event Year & $\begin{array}{c}\text { Intra-network } \\
\text { consolidations }\end{array}$ & Other consolidations Control banks \\
& 5 & 12 & 414 \\
1927 & 9 & 19 & 376 \\
1928 & 6 & 15 & 285 \\
1929 & 20 & 46 & 1075 \\
\hline Total & 2 & &
\end{tabular}


Table13 The effect of consolidations on deposit growth rate

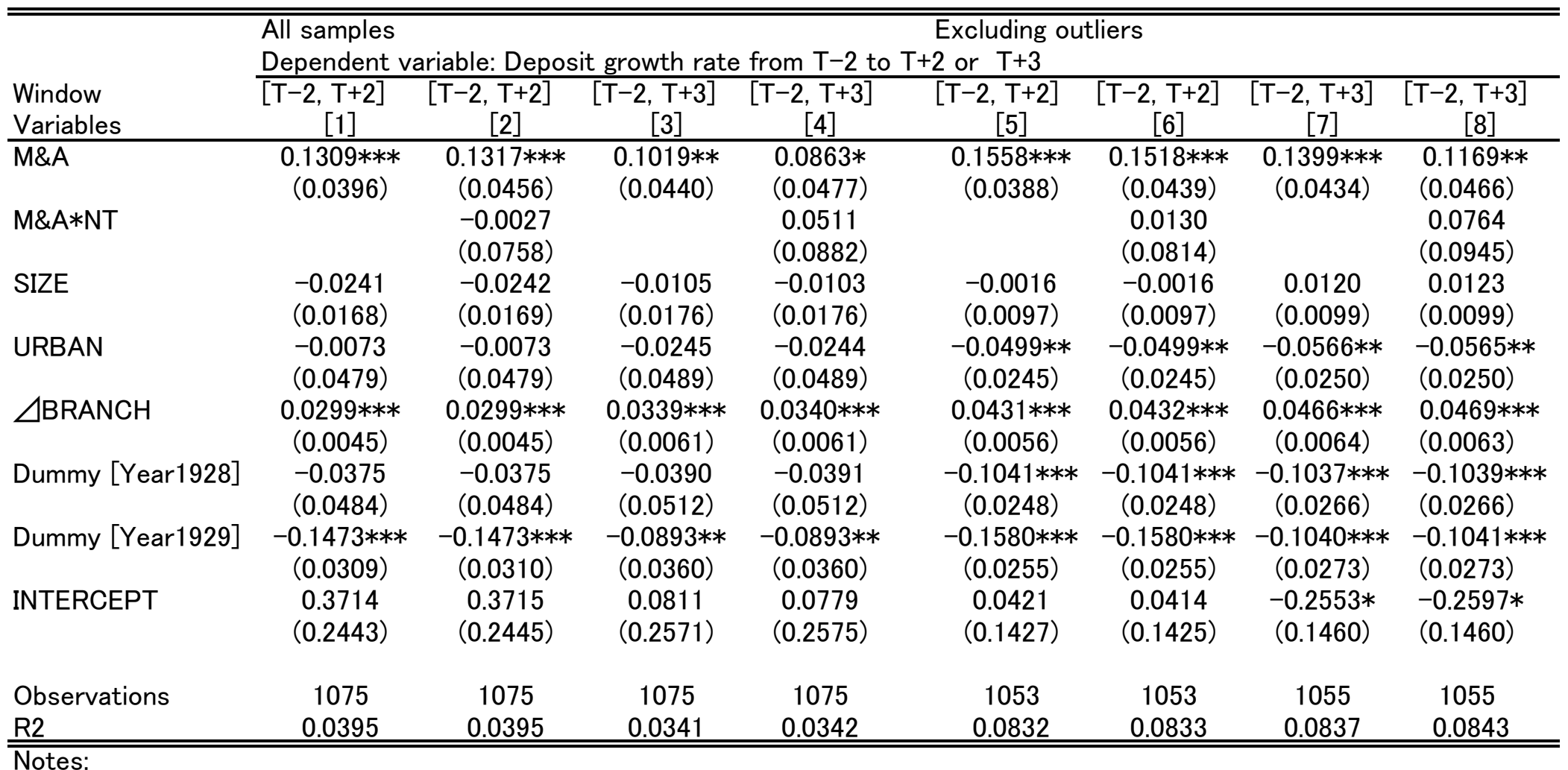

Notes:

Significance at $1 \%, 5 \%$ and $10 \%$ level are denoted by " $* * *$ " " $* *$ " and " $*$ ".

The figures in parentheses are standard errors. 
Table14 The effect of consolidations on ROA

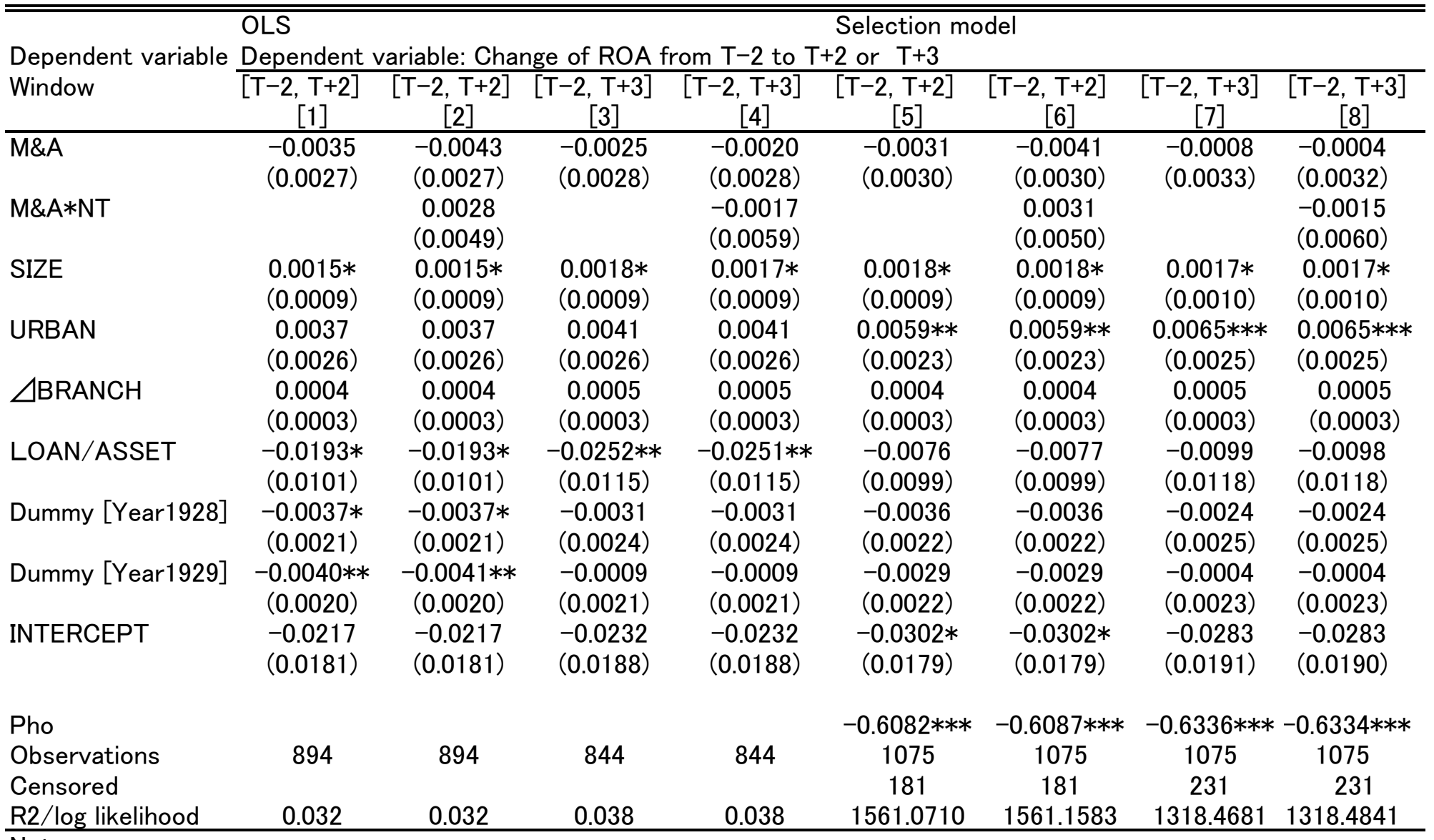

\section{Notes:}

Significance at $1 \%, 5 \%$ and $10 \%$ level are denoted by "***" "**" and "*".

The figures in parentheses are standard errors. 
Appendix Table1 Interbank networks and contagious withdrawal of deposits (Selection model)

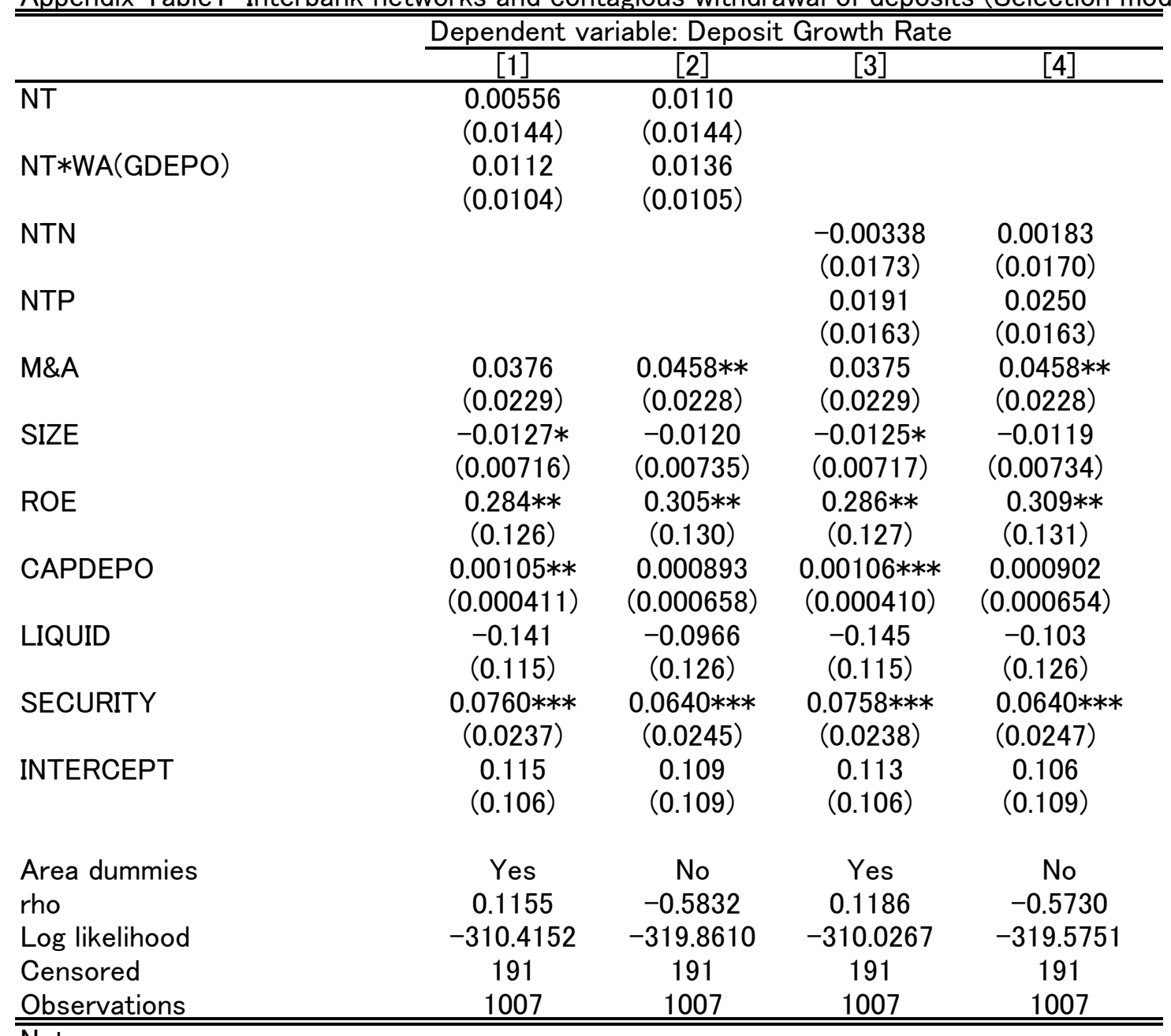

Notes:

Significance at $1 \%, 5 \%$ and $10 \%$ level are denoted by "***" " $* *$ " and " $*$ ".

The figures in parentheses are standard errors. 